\title{
LETTERS
}

\section{Efficacy of infliximab in psoriatic arthritis resistant to treatment with disease modifying antirheumatic drugs: an open pilot study}

\author{
G Provenzano, A Termini, C Le Moli, F Rinaldi
}

Ann Rheum Dis 2003;62:680-681

$\mathrm{P}$ soriatic arthritis (PsA) used to be considered a mild disease, but the development of erosive and deforming arthritis has been shown in a large proportion of patients. ${ }^{1}$

Disease modifying antirheumatic drugs (DMARDs) often do not achieve a satisfactory control of articular symptoms and there is no evidence of their effect on the progression of joint damage. ${ }^{2}$ Tumour necrosis factor $\alpha(\mathrm{TNF} \alpha)$ has a role in the pathogenesis of $\mathrm{PsA}^{3}$ and there are some encouraging reports about the efficacy of TNF $\alpha$ neutralising agents for the treatment of the spondyloarthropathies, including PsA. ${ }^{4-8}$

\section{METHODS AND RESULTS}

We evaluated in an open label, six month pilot study the safety and efficacy of infliximab in association with methotrexate (MTX) in 12 patients with PsA resistant to conventional DMARD treatment.

Patients were considered eligible for the study if they fulfilled all of the following criteria: (a) diagnosis of psoriasis confirmed by a dermatologist; $(b)$ diagnosis of spondyloarthropathy according to the European Spondyloarthropathy Study Group criteria9; (c) active disease despite treatment with MTX + steroids + non-steroidal anti-inflammatory drugs (NSAIDs); active disease was defined as the presence of at least one swollen joint, active tendonitis or dactylitis in one tendon or finger, and/or inflammatory spinal pain. ${ }^{5}$

Four men and eight women were enrolled, with a mean (SD) age of 48.4 (13.6) years, a mean duration of cutaneous disease of 15.5 (10.5) years, and a mean duration of articular symptoms of 8.6 (5.6) years. Eleven patients had a polyarthritis with prevalent peripheral arthritis and only one patient had a predominantly axial disease.

All the patients had been treated with MTX to which they did not respond and seven patients had also been unresponsive to combination therapy (MTX plus sulfasalazine and/or cyclosporin). Five patients required steroid treatment at baseline (prednisone $\geqslant 5 \mathrm{mg}$ daily). Treatment with MTX was maintained throughout the study at the dose and schedule regimen used in the two months before inclusion in the study ( $15 \mathrm{mg} /$ week for nine patients, $10 \mathrm{mg} /$ week for three). Steroids and NSAIDs were allowed during the study, provided that the doses did not exceed those used at the study entrance. DMARDs other than MTX had to be discontinued at least two months before entrance to the study.

Infliximab at a dose of $5 \mathrm{mg} / \mathrm{kg}$ was given at weeks 0 (baseline), 2, 6, 14, and 22. The following outcome measures of disease activity were evaluated at weeks 0 (baseline), 2, 6, 10, 14, 22, and 26: patient global health status, pain, and disease activity; Health Assessment Questionnaire; doctor global disease activity; tender and swollen joint count; psoriasis activity skin index; erythrocyte sedimentation rate (ESR) and $\mathrm{C}$ reactive protein (CRP) (table 1). The American College of Rheumatology (ACR) improvement criteria for rheumatoid arthritis with $20 \%, 50 \%$, and $70 \%$ improvement were also assessed.

At week 10 a significant decrease $(p \leqslant 0.01)$ was seen for all variables with the exception of the tender joint count, ESR, and CRP. At week 26 this decrease was even stronger for many variables and a significant decrease was seen also for the tender joint count and CRP as compared with baseline values.

At week 10 six patients met the ACR20 criteria for improvement; five of them also met the ACR50, three the ACR70. At week 2610 patients met the ACR20 criteria (all the patients still receiving treatment with infliximab); six of them also met the ACR50, four the ACR70. At week 26 only two patients still required steroid treatment, both of them at a lower dose than at the study entrance.

Infliximab was well tolerated in all patients and we did not see any infusion reaction or delayed hypersensitivity reaction. Two patients were withdrawn from the study because of the occurrence of serious events. One patient was admitted to hospital for angina pectoris after the third infusion and we decided to stop the study treatment. Another patient withdrew from the study after the fourth infusion when a pulmonary

Table 1 Outcome measures at baseline, and at weeks 10 and 26. Values are given as mean (SD)

\begin{tabular}{llll}
\hline & $\begin{array}{l}\text { Baseline } \\
(12 \text { patients) }\end{array}$ & $\begin{array}{l}\text { Week 10 } \\
(12 \text { patients) }\end{array}$ & $\begin{array}{l}\text { Week 26 } \\
\text { (10 patients) }\end{array}$ \\
\hline Patient global health status (0-100) & $28.3(22.1)$ & $56.7(30.5)^{*}$ & $63.0(23.6)^{*}$ \\
Patient pain (0-100) & $84.2(17.3)$ & $54.2(32.3)^{*}$ & $33.0(27.1)^{*}$ \\
Patient global disease activity (0-100) & $82.5(18.6)$ & $54.2(30.9)^{*}$ & $28.0(16.2)^{*}$ \\
Health Assessment Questionnaire & $2.0(0.6)$ & $1.2(1.2)^{*}$ & $0.9(1.1)^{*}$ \\
Doctor global disease activity (0-100) & $74.2(14.4)$ & $49.2(30.9)^{*}$ & $27.0(17.0)^{*}$ \\
Tender joint count & $31.7(22.9)$ & $24.2(29)$ & $9.6(12.7)^{*}$ \\
Swollen joint count & $9.9(6.8)$ & $5.8(7.5)^{*}$ & $2.3(4.6)^{*}$ \\
PASI (psoriasis activity skin index) & $12.1(10.3)$ & $1.7(5.6)^{*}$ & $1.1(2.7)^{*}$ \\
ESR (mm/1sth) & $21.6(15.5)$ & $15.9(9.4)$ & $20.2(20.4)$ \\
CRP (mg/l) & $0.9(0.9)$ & $0.7(1.3)$ & $0.2(0.4)^{*}$ \\
\hline
\end{tabular}

${ }^{*} p \leqslant 0.01$ as compared with baseline (determined by $t$ test for paired data). 
malignancy occurred. In both of these cases it is unlikely that there was a correlation between the adverse event and the study treatment, especially as the treatment was short.

\section{DISCUSSION}

Our data confirm the efficacy of infliximab in patients with PsA, suggesting that it may be the preferred treatment for patients resistant to conventional DMARDs.

In other reports the efficacy of treatment with anti-TNF $\alpha$ agents on PsA was less pronounced ${ }^{4}$ than in our study. This may be due to several factors, including the selection of the patients ( 11 of our 12 patients had a peripheral polyarthritis) and the therapeutic regimen (the association of MTX with infliximab might have enhanced its therapeutic effect). The maximum effect of this treatment on articular symptoms may not be apparent after the loading dose regimen of three infusions, but seen later on. Controlled studies and longer follow up are needed to optimise the selection of patients who can benefit from this form of treatment.

Authors' affiliations

G Provenzano, Department of Internal Medicine, Section of Autoimmune Diseases, A.O. "Villa Sofia - CTO", Palermo, Italy

A Termini, C Le Moli, F Rinaldi, Division of Internal Medicine II, A.O.

"V Cervello", Palermo, Italy
Correspondence to: Dr G Provenzano, Via Massimo d'Azeglio No 2 90143 Palermo, Italy; giuseppe.provenzano5@tin.it

Accepted 30 November 2002

\section{REFERENCES}

1 Gladman DD, Stafford-Brady F, Chang C-H, Lewandoski K, Russell ML. Longitudinal study of clinical and radiological progression in psoriatic arthritis. J Rheumatol 1990;17:809-12.

2 Abu-Shakra M, Gladman DD, Thorne JC, Long J, Gough J, Farewell VT. Long-term methotrexate therapy in psoriatic arthritis: clinical and radiological outcome. J Rheumatol 1995:22:241-5.

3 Mease PJ. Tumour necrosis factor (TNF) in psoriatic arthritis: pathophysiology and treatment with TNF inhibitors. Ann Rheum Dis 2002;61:298-304.

4 Mease PJ, Gaffe BS, Metz J, Vanderstoep A, Finck B, Burge DJ. Etanercept in the treatment of psoriatic arthritis and psoriasis: a randomised trial. Lancet 2000;356:385-90.

5 Van den Bosch F, Kruithof E, Baeten D, De Keyser F, Mielants H, Veys EM. Effects of a loading dose of three infusions of chimeric monoclonal antibody to tumour necrosis factor (infliximab) in spondyloarthropathy: an antibody to tumour necrosis factor (infliximab) in spond
open pilot study. Ann Rheum Dis 2000;59:428-33.

6 Braun J, Brandt J, Listing A, Zink A, Alten R, Golder F, et al. Treatment of active ankylosing spondylitis with infliximab: a randomised controlled multicentre trial. Lancet 2002;357:1 187-93.

7 Gorman JD, Sack KE, Davis JC. Treatment of ankylosing spondylitis by inhibition of tumour necrosis factor $\alpha$. N Engl J Med 2002;346:1349-56.

8 Kruithof E, Van den Bosch F, Baeten D, Herssens A, De Keiser F,

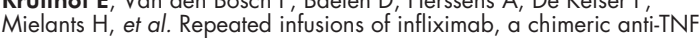
Mielants $\mathrm{H}$, et al. Repeated infusions of infliximab, a chimeric anti-TNF
monoclonal antibody, in patients with active spondyloarthropathy: one monoclonal antibody, in patients with active spondyloc year follow up. Ann Rheum Dis 2002;61:207-12.

9 Dougados M, van der Linden S, Juhlin R, Huitfeldt B, Amor B, Calin A et al. The European Spondyloarthropathy Study Group preliminary criteria for the classification of spondyloarthropathy. Arthritis Rheum $1991 ; 34: 1218-27$

\section{Twenty eight joint count disease activity score in recent onset rheumatoid arthritis using $\mathrm{C}$ reactive protein instead of erythrocyte sedimentation rate}

\section{T Skogh, D Gustafsson, M Kjellberg, M Husberg}

C reactive protein (CRP) and erythrocyte sedimentation rate (ESR) are traditional markers of disease activity in rheumatoid arthritis (RA). Although the two tests show a relatively high degree of correlation and follow the same reaction pattern, the variance of CRP is independent of ESR to some extent. ${ }^{1}$ Apart from mirroring inflammation, ESR is affected by immunoglobulin levels, sex, and abnormal size or shape of red blood cells. ${ }^{2}{ }^{3}$ CRP, which correlates more significantly than ESR with disease activity, ${ }^{13}{ }^{4}$ is a predictor of functional status/outcome and joint damage in $\mathrm{RA}^{5-7} \mathrm{Al}-$ though CRP is the better marker of inflammation, ESR adds information reflecting disease severity, ${ }^{8}$ and a combination of the tests may be worthwhile.

To create a simple instrument for assessment of disease activity in RA, Prevoo et al developed a disease activity score (DAS28) based on the number of tender and swollen joints $(\mathrm{n}=28)$, ESR, and the patient's self estimated general health. ${ }^{9}$ DAS28 has become an important tool for rheumatologists to monitor disease activity. However, considering its better indication of disease activity, it would be preferable if the CRP value could be used as an alternative to ESR for calculation of the DAS. Paulus et al constructed a nomogram to convert CRP values to ESR, ${ }^{10}$ which in turn could be successfully used to calculate the traditional DAS.

In our study we investigated whether it was possible simply to use the numerical value of CRP concentration $(\mathrm{mg} / \mathrm{l})$ instead of ESR ( $\mathrm{mm} / \mathrm{lst} \mathrm{h}$ ) for the calculation of DAS28. Seventy patients with recent onset RA ( $\leqslant 1$ year) were included from the ongoing Swedish early RA cohort designated "TIRA". Each patient was seen by the same rheumatologist at inclusion and after 3, 6, 12, 18, and 24 months. The patients' assessments of general health assessed by a visual analogue scale $(\mathrm{mm})$, the number of swollen and tender joints respectively (28 joint counts), ESR ( $\mathrm{mm} / \mathrm{lst} \mathrm{h}$ ), and plasma CRP (mg/l) were registered at all visits. CRP was analysed by turbidimetry at the hospital laboratory and the results presented as $<10$ or a value without decimals from 10 with no upper limit. CRP $<10$ was given the value 5 . In comparing ESR and CRP, 398 cases were analysed. The traditional DAS28 (DAS28/ESR) was calculated using the formula presented by Prevoo et al. ${ }^{9}$ A DAS28 based on CRP instead of ESR was also calculated by substituting the numerical value of ESR in the formula by plasma CRP (DAS28/CRP).

The mean (SD) ESR was $25.4(2.73) \mathrm{mm} / \mathrm{lst} \mathrm{h}$ (range 2-105). CRP ranged from 5 to $122 \mathrm{mg} / \mathrm{l}$ with a mean (SD) value of 15.65 (19.16). Figure 1A illustrates the correlation between individual CRP and ESR values (Spearman's correlation coefficient, $r_{\mathrm{s}}=0.69$ ). Figure $1 \mathrm{~B}$ illustrates the linear correlation between the two modes of DAS28 calculation $\left(r_{\mathrm{s}}=0.93\right)$. DAS28 based on ESR ranged from 0.50 to 8.50 (mean (SD) $4.04(1.48)$ ) and DAS28/CRP ranged from 1.14 to 8.00 (mean (SD) $3.68(1.46)$ ). Thus the mean (SD) DAS28/ESR of 4.04 (1.48)was not statistically different from DAS28/CRP (3.68 (1.46))

To conclude, the correlation between ESR and plasma CRP in this study was within the same magnitude as that reported 

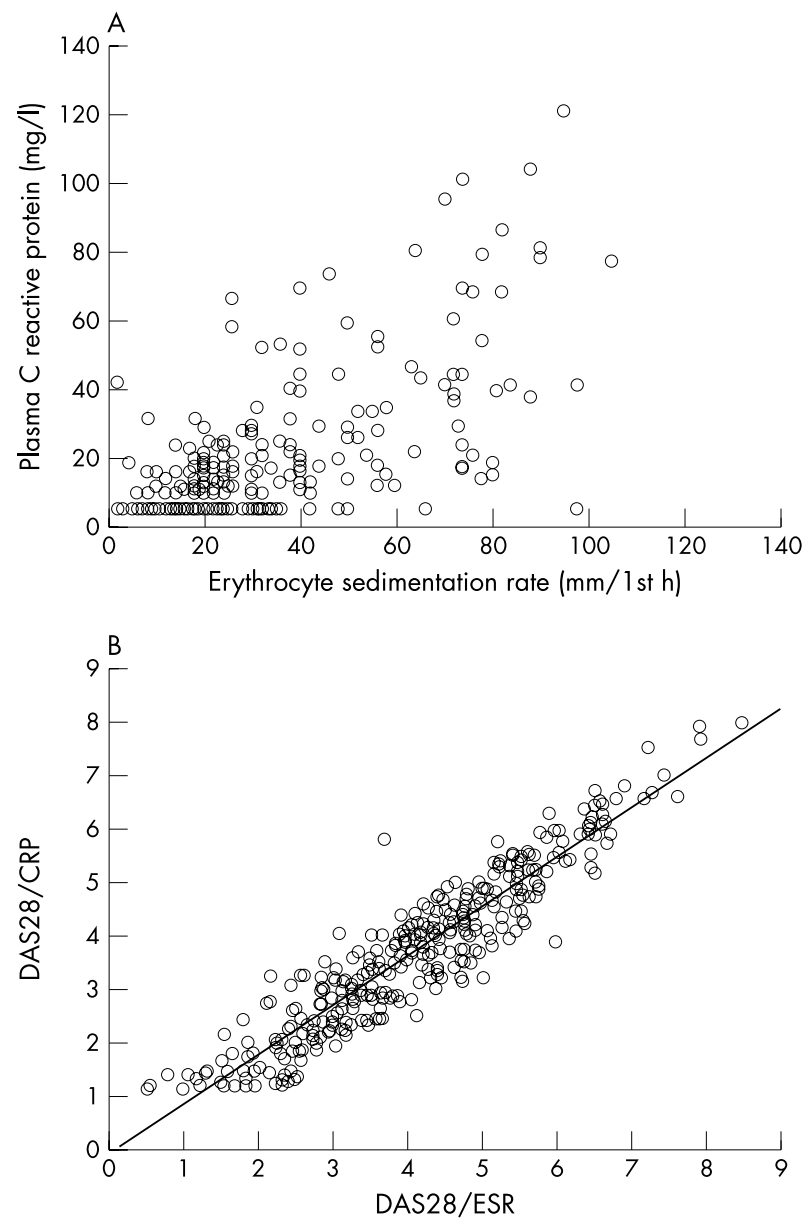

Figure 1 Comparison of ESR and plasma CRP (A), and DAS28 calculated with CRP and ESR respectively (B).

in previous studies on RA. ${ }^{14}$ Although the two values were by no means interchangeable, the correlation between the "orthodox" DAS28 and DAS28 based on plasma CRP was remarkably high, because the weight of the laboratory test is low and thus has only a small impact on the disease activity score compared with the other measures.
These findings may be useful to all rheumatologists who prefer CRP as a laboratory marker of inflammation in RA, and who do not have access to ESR values for the calculation of the DAS28.

\section{ACKNOWLEDGEMENTS}

We thank Ylva Billing and Ingrid Thyberg for helpful collaboration. This study was financed by grants from the Health Research Council in the southeast of Sweden and by the Swedish Rheumatism Association.

\section{Authors' affiliations}

T Skogh, D Gustafsson, M Kiellberg, Division of Rheumatology, Department of Molecular and Clinical Medicine, Faculty of Health Sciences, Linköping University Hospital, SE-581 85 Linköping, Sweden M Husberg, Centre for Medical Technology Assessment, Linköping, Sweden

Correspondence to: Professor T Skogh; thomas.skogh@lio.se

Accepted 2 December 2002

\section{REFERENCES}

1 Mallya R, de Beer FC, Berry H, Hamilton EDB, Mace BEW, Pepys MB. Correlation of clinical parameters of disease activity in rheumatoid arthritis with serum concentration of C-reactive protein and erythrocyte sedimentation rate. J Rheumatol 1982;9:224-8.

2 Talstad I, Scheie P, Dalen H, Roli J. Influence of plasma proteins on erythrocyte morphology and sedimentation. Scand J Haematol 1983;31:478-84.

3 Kushner I. C-reactive protein in rheumatology. Arthritis Rheum 1991;34:1065-8.

4 Wolfe, F. Comparative usefulness of C-reactive protein and erythrocyte sedimentation rate in patients with rheumatoid arthritis. J Rheumatol 1997;24:1477-85

5 Jansen LM, van Schaardenburg D, van Der Horst-Bruinsma IE, Bezemer PD, Dijkmans BA. Predictors of functional status in patients with early rheumatoid arthritis. Ann Rheum Dis 2000;59:223-6.

6 Jansen LMA. Predictors of radiographic joint damage in patients with early rheumatoid arthritis. Ann Rheum Dis 2001;60:924-7.

7 Devlin J, Gough A, Huissoon A, Perkins P, Holder R, Reece R, et al. The acute phase and function in early rheumatoid arthritis. C-reactive protein levels correlate with functional outcome. J Rheumatol 1997;24:9-13.

8 Bull BS, Westengard JC, Farr M, Bacon PA, Meyer PJ, Stuart J. Efficacy of tests used to monitor rheumatoid arthritis. Lancet 1989;ii:965-7.

9 Prevoo MLL, van't Hof MA, Kuper HH, van Leeuwen MA, van de Putte LBA, van Riel PLCM. Modified disease activity scores that include twenty-eight-joint counts. Arthritis Rheum 1995:38:44-8.

10 Paulus HE, Ramos B, Wong WK, Ahmed A, Bulpitt K, Park G, Sterz M, et al. Equivalence of the acute phase reactants $C$-reactive protein, plasma viscosity, and Westergren erythrocyte sedimentation rate when used to calculate American college of rheumatology $20 \%$ improvement criteria or the disease activity score in patients with early rheumatoid arthritis. J Rheumatol 1999;26:2324-31.

\title{
Horner's syndrome as an initial manifestation of Takayasu's arteritis
}

\author{
J-W Chung, Y-J Suh, J-H Choi, H-S Park, J-H Won, C-H Suh
}

$\mathrm{T}$ akayasu's arteritis (TA) is a granulomatous vasculitis of the large arteries. It typically produces segmental arterial narrowing and occlusion, but aneurysm formation is uncommon. ${ }^{1}$ Subclavian artery aneurysm presenting with Horner's syndrome is very rare. ${ }^{2}$ We report on a patient with Horner's syndrome caused by subclavian artery aneurysm in TA.

\section{CASE REPORT}

A 37 year old Korean man was admitted because of right side ptosis and anhidrosis. He had visited the ophthalmology department three weeks previously. Initially, his margin reflex distance $\mathrm{l}\left(\mathrm{MRD}_{1}\right)$ was $1.5 \mathrm{~mm}$ (right) and $3.0 \mathrm{~mm}$ (left). The neostigmine test was performed, but the $\mathrm{MRD}_{1}$ did not change. After administration of phenylephrine 1 drop, however, $\mathrm{MRD}_{1}$ was improved to $3.0 \mathrm{~mm}$ in the right eye. Horner's syndrome was diagnosed. He had no trauma history. He did not complain of any claudication, pain, or dizziness. His blood pressure was $110 / 70 \mathrm{~mm} \mathrm{Hg}$ in both arms and pulse rate 80 beats/min. Complete blood counts, serum protein, and urine analysis were normal. Antinuclear antibody and rheumatoid factor were 

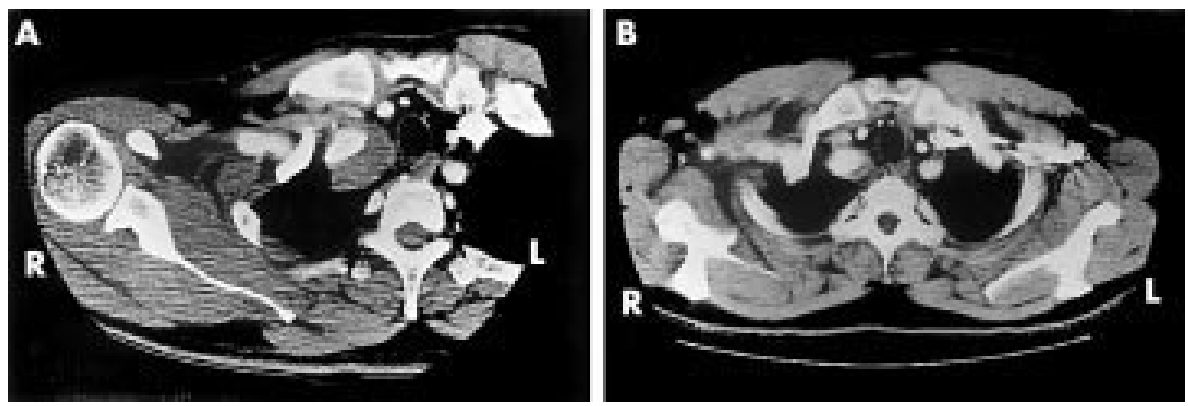

Figure 1 (A) CT image of the chest, showing a $4 \mathrm{~cm}$ sized focal aneurysm dilation of the right subclavian artery at the thoracic inlet level with mural thrombi. (B) After three months, the follow up CT image of the chest, showing the markedly decreased size of the subclavian and vertebral artery aneurysms and no evidence of newly developed lesions.
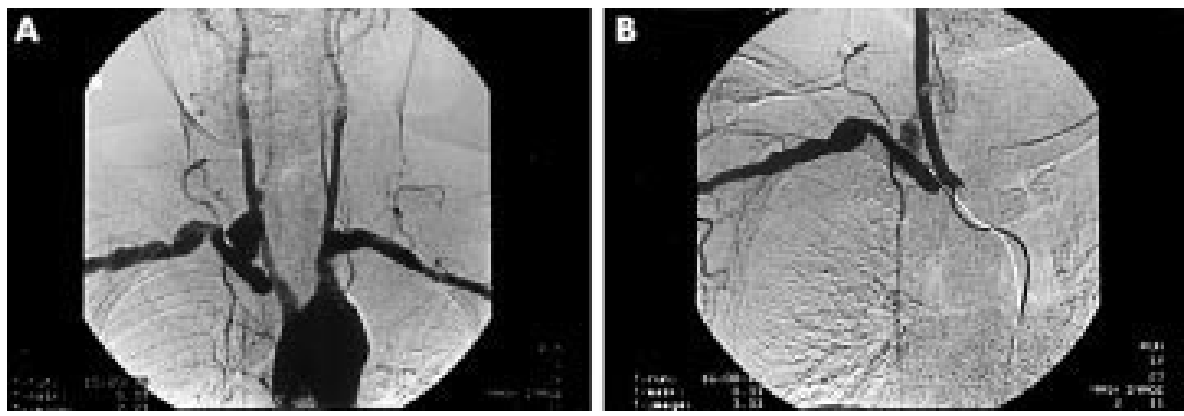

Figure 2 (A) Angiographic appearance of the right subclavian and proximal part of the right vertebral artery aneurysm. (B) Angiographic appearance of stent-graft in the right subclavian artery.

negative. Erythrocyte sedimentation rate (ESR) at $70 \mathrm{~mm} / \mathrm{lst} \mathrm{h}$ and $\mathrm{C}$ reactive protein at $25 \mathrm{mg} / \mathrm{l}$ were raised.

Chest computed tomography (CT) showed a $4 \mathrm{~cm}$ sized aneurysmal dilation of the right subclavian artery at the thoracic inlet level with mural thrombi (fig lA) and the proximal part of the right vertebral artery. Angiography also showed aneurysmal dilation (fig 2A). In this case, both the involvement of the subclavian and vertebral artery and the elimination of other possible causes in a young man led to the diagnosis of TA.

After CT and angiography, daily treatment with $60 \mathrm{mg}$ prednisolone was started owing to high inflammatory markers. We inserted a stent-graft in the right subclavian artery (fig 2B) and coiling in the right vertebral artery after the inflammation resolved. Follow up CT showed well enhanced lumen of the subclavian artery stent and no evidence of enhancement of the aneurysm. He was discharged with slightly improved ptosis on a regimen of prednisolone 60 mg daily. Anhidrosis, however, was not improved. The prednisolone dosage was slowly tapered. After three months, he took daily $12.5 \mathrm{mg}$ prednisolone and $100 \mathrm{mg}$ azathioprine, and follow up CT showed the markedly decreased size $(1 \mathrm{~cm})$ of the subclavian artery aneurysm (fig 1B).

\section{DISCUSSION}

The clinical manifestation of Horner's syndrome is unilateral miosis, ptosis, and ipsilateral anhidrosis, and major causes include neoplasms, cysts, or inflammatory diseases. At initial evaluation, chest CT was done to evaluate the possibility of malignancy in the thorax. Subclavian and vertebral artery aneurysms were disclosed.

Takayasu's arteritis is a chronic granulomatous inflammatory vasculitis. A "triphasic" pattern has been described. ${ }^{1}$ Phase I is characterised by non-specific systemic complaints. Phase II is dominated by vessel pain due to vessel inflammation. Phase III refers to the fibrotic stage, in which bruits and ischaemia predominate. In some series about $16 \%$ of patients had constitutional symptoms, and $10 \%$ were asymptomatic. ${ }^{3}$ In addition, both inflammatory and fibrotic changes may be present simultaneously. Aneurysms in TA are uncommon and the incidence varies from $4.9 \%$ to $31.9 \% .{ }^{4}$ The most common site is the aorta, followed by the subclavian artery. In our patient there were no constitutional symptoms, bruit, or ischaemic symptoms. No laboratory test is specific for TA. The ESR is often used to assess disease activity. ${ }^{6}$ Computed tomography of the chest and abdomen may be helpful in evaluating large arteries, and serial examinations may thus be useful. ${ }^{7}$

For active TA, glucocorticoids are the first treatment. Corticosteroids effectively suppress the systemic symptoms and usually arrest progression. The raised acute phase reactants also return to normal. ${ }^{8}$ Arterial stenosis may reverse and ischaemic symptoms may improve in early cases. We started $60 \mathrm{mg}$ of daily prednisolone and gradually reduced the dose when the inflammatory process improved. Open surgical repair was the definitive treatment for vascular lesions, such as aneurysms. However, the success rate has not been high because a false aneurysm often occurs. To avoid surgical complications, endovascular methods, such as insertion of a stent-graft, have been recommended because they are less invasive. Recently, stent-graft placement has been indicated for the treatment of aneurysms. ${ }^{9}$ The technical success rate of stent-graft insertion is $>90 \%$. In our case, aneurysm size decreased rapidly after stent-graft insertion.

This is, to our knowledge, the first report of a patient with TA manifested by Horner's syndrome. When Horner's syndrome is diagnosed, a common cause is neoplasms. However, Horner's syndrome may be the first symptom of TA.

\section{Authors' affiliations}

J-W Chung, Y-J Suh, J-H Choi, H-S Park, C-H Suh, Department of

Allergy-Rheumatology, Ajou University School of Medicine, Suwon, South Korea

J-H Won, Department of Radiology, Ajou University School of Medicine, Suwon, South Korea

Correspondence to: $\mathrm{Dr}$ C-H Suh, Department of Allergy-Rheumatology, Ajou University School of Medicine, Paldalgu Woncheondong San-5, Suwon, South Korea 442-721; chsuh@ajou.ac.kr

Accepted 2 December 2002 


\section{REFERENCES}

1 Hall S, Barr W, Lie JT, Stanson AW, Kazmier FJ, Hunder GG. Takayasu arteritis. A study of 32 North American patients. Medicine (Baltimore) 1985;64:89-99.

2 Levent E, Posacioglu H. A rare cause of Horner's syndrome: subclavian artery aneurysm. Respiration 2001;68:620.

3 Sharma BK, Sagar S, Singh AP, Suri S. Takayasu arteritis in India. Heart Vessel 1992;7(suppl):37-43

4 Deutsch V, Wexler L, Deutsch H. Takayasu's arteritis. An angiographic study with remarks on ethnic distribution in Israel. Am J Roentgenol Radium Ther Nucl Med 1974;122:13-28.
5 Matsumura K, Hirano T, Takeda K, Matsuda A, Nakagawa T, Yamaguchi $N$, et al. Incidence of aneurysms in Takayasu's arteritis. Angiology 1991;42:308-15.

6 Fraga A, Mintz G, Valle L, Flores-lzquierdo G. Takayasu's arteritis. Frequency of systemic manifestations (study of 22 patients) and favorable response to maintenance steroid therapy with adrenocorticosteroids (12 patients). Arthritis Rheum 1972;15:617-24.

7 Paul JF, Fiessienger JN, Sapoval M, Hernigou A, Mousseaux E, Emmerich J, et al. Follow-up electron beam CT for the management of early phase Takayasu arteritis. J Comput Assist Tomogr 2001;25:924-31. Kerr G. Takayasu's arteritis. Rheum Dis Clin North Am 1095:21:1041-58. 9 Henry M, Amor M, Cragg A, Porte JM, Henry I, Amicabile C, et al. Occlusive and aneurysmal peripheral arterial disease: assessment of a stent-graft system. Radiology 1996;201:717-24.

\title{
Kaposi's sarcoma associated with tumour necrosis factor $\alpha$ neutralising therapy
}

\author{
C D Cohen, S Horster, C A Sander, J R Bogner
}

Ann Rheum Dis 2003;62:684

nhibition of tumour necrosis factor $\alpha$ (TNF $\alpha)$ by antibodies or soluble receptors has developed as a potent treatment of chronic inflammatory diseases like rheumatoid arthritis (RA) or Crohn's disease. Because TNF $\alpha$ is an important mediator in the inflammatory response, this blockade led to the concern of increased risk of severe infections or malignancies. Despite reassuring data from clinical trials, an association between TNF $\alpha$ inhibition and tuberculosis has been shown, and several cases of serious infections and malignant complications have been described..$^{1-3}$

We report the case of Kaposi's sarcoma (KS), a malignancy with infectious pathogenesis, ${ }^{4}$ associated with the initiation of TNF $\alpha$ blockade by the humanised, mouse derived monoclonal antibody infliximab.

\section{CASE REPORT}

A 69 year old Turkish woman with a 25 year history of severe RA presented with multiple firm, purple-reddish plaques and nodules covering her left lower leg. The lesions had started to develop a few weeks after initiation of infliximab and had progressed during the past 18 months. In this time she had received 12 doses of $3 \mathrm{mg} / \mathrm{kg}$ infliximab. The first six doses were given during concurrent methotrexate treatment until she developed a pneumonitis. Subsequently, she had three infusions in combination with leflunomide. This was discontinued owing to increased liver enzymes. Before infliximab, several treatments were stopped owing to adverse reactions or lack of efficacy.

At the time of presentation she received methylprednisolone (12 mg/day) and rofecoxib ( $25 \mathrm{mg} /$ day) concomitantly with the TNF $\alpha$ inhibition. A biopsy of one of the lesions revealed KS. Histopathological examination showed expansion of spindle cell vascular processes and the tissue was stained positive for human herpes virus 8 (HHV8). The patient tested serologically positive for HHV8, but negative for HIV. Her total lymphocytes were 871 cells/ $\mu$ l with an absolute CD4+ cell count of 391 cells/ $\mu$ l (45\%). The patient did not report any family history of endemic KS. Her husband tested negative for HHV8. Screening for antinuclear or antineutrophil cytoplasmic antibodies was negative. Mycobacteria or
Bartonella were excluded by microbiological and serological tests, and a negative tuberculin skin test. Investigations for metastasis disclosed no abnormal findings.

\section{DISCUSSION}

Iatrogenic KS has been described in immunosuppressed patients. ${ }^{4}$ It occurs mainly in recipients of organ transplant but has also been reported in other patients with chronic immunosuppressive treatment. ${ }^{5}$ The patient reported here originated from Turkey, a region with an increased risk for iatrogenic KS. ${ }^{6}$

As far as we know, KS in coincidence with initiation of TNF $\alpha$ neutralising therapy has not been reported previously. Therefore, a causal connection between TNF $\alpha$ inhibition and KS is unclear. None the less, monitoring patients for skin tumours might be advisable during treatment with TNF $\alpha$ antagonists, and special care may be needed in patients with increased risk for iatrogenic KS. ${ }^{6}$

\section{Authors' affiliations}

C D Cohen, S Horster, C A Sander, J R Bogner, University of Munich, Germany

Correspondence to: $\operatorname{Dr}$ C D Cohen, Medizinische Poliklinik, University of Munich, Pettenkoferstr 8a, 80336 Munich, Germany; c.cohen@web.de

Accepted 16 December 2002

\section{REFERENCES}

1 Keane J, Gershon S, Wise RP, Mirabile-Levens E, Kasznica J, Schwieterman WD, et al. Tuberculosis associated with infliximab, a tumor necrosis factor alpha-neutralizing agent. N Engl J Med 2001;345:1098-104

2 Day R. Adverse reactions to TNF-alpha inhibitors in rheumatoid arthritis. Lancet 2002;359:540-1.

3 Phillips K, Husni ME, Karlson EW, Coblyn JS. Experience with etanercept in an academic medical center: are infection rates increased? Arthritis Rheum 2002;47:17-21.

4 Hengge UR, Ruzicka T, Tyring SK, Stuschke M, Roggendorf $M$, Schwartz RA, et al. Update on Kaposi's sarcoma and other HHV8 associated diseases, parts I and II. Lancet Infect Dis. 2002;2:281-92, 344-52.

5 Casoli P, Tumiati B. Rheumatoid arthritis, corticosteroid therapy and Kaposi's sarcoma: a coincidence? A case and review of literature. Clin Rheumatol 1992; 1 1:432-5.

6 Iscovich J, Boffetta P, Franceschi S, Azizi E, Sarid R. Classic Kaposi sarcoma: epidemiology and risk factors. Cancer 2000;88:500-17. 


\title{
Factors influencing uptake of influenza vaccination in patients with rheumatoid arthritis
}

\author{
M J Bridges, D Coady, C A Kelly, J Hamilton, C Heycock
}

Ann Rheum Dis 2003;62:685

R ecent British Society for Rheumatology (BSR) guidelines ${ }^{1}$ have advised that all patients with rheumatoid arthritis (RA) receiving methotrexate (MTX), cyclosporin A, or azathioprine should receive an annual influenza vaccination. Because there are relatively few data about immunisation rates in patients with RA, we undertook a study with the following aims: (a) to document the rate of uptake of influenza vaccine in patients with RA; $(b)$ to assess the degree of conformity to the BSR guidelines; (c) to explore the factors that influence vaccine uptake.

One hundred and twenty nine consecutive patients with RA were assessed between September 2001 and February 2002 during their routine hospital outpatient appointment. At the end of the consultation, the doctor inquired about vaccination status using standardised questionnaires. Information about whether the patient had been immunised during the previous 12 months was based on the patient's self report. Other data collected from the case notes and by direct questioning included age, year of diagnosis, duration of RA, presence or absence of rheumatoid factor (RF), drugs taken, and presence of other recognised indications for influenza vaccination. Table 1 shows the demographics of the 129 patients questioned.

Of the 114 patients receiving disease modifying antirheumatic drugs (DMARDs), 59 were taking MTX, 4 azathioprine, and 58 other DMARDs. No patients were taking cyclosporin A, and 7 patients were taking a combination of DMARDs. In total, $73(57 \%)$ of the patients with RA had received the influenza vaccine in the previous 12 months.

Awareness of vaccination by patients who had received it came from different sources, and is shown in table 2. Advice about immunisation mainly came from primary care, with the secondary care sector contributing little to patient information.

The commonest reason cited by patients for non-uptake of vaccination were: "never offered vaccine" (42\%), "concerns over side effects" (19\%), beliefs of vaccine inefficacy (10\%), and "not aware of need" (5\%); $24 \%$ of patients quoted other reasons.

Thirty three $(56 \%)$ patients taking MTX had received the influenza vaccine. No patients were taking cyclosporin and only four patients were taking azathioprine, so no meaningful comparison could be made with BSR guidelines for these drugs.

Table 1 Demographic characteristics of the patients with RA. Results are shown as No (\%)

\begin{tabular}{lcc}
\hline Number & 129 & \\
Women & 89 & $(69)$ \\
Mean age (years) & 59.4 & \\
$>65$ years & 44 & $(34)$ \\
Mean disease duration (years) & 8.0 & \\
RF positive & 93 & $(72)$ \\
Receiving DMARDs & 114 & $(88)$ \\
Receiving corticosteroids & 14 & $(11)$ \\
Ischaemic heart disease & 11 & $(9)$ \\
Diabetes mellitus & 4 & $(5)$ \\
Chronic pulmonary disease & 16 & $(12)$ \\
Chronic renal disease & 1 & $(1)$ \\
Chronic liver disease & 1 & $(1)$ \\
\hline
\end{tabular}

Table 2 Source of information about vaccination for the 73 patients with RA who had been vaccinated. Results are shown as No (\%)

\begin{tabular}{lc}
\hline & Influenza vaccinee \\
\hline GP & $52(71)$ \\
Practice nurse & $12(16)$ \\
Hospital doctor & $7(10)$ \\
Rheumatology nurse & 0 \\
Family/friends & $2(3)$ \\
\hline
\end{tabular}

Patients with ischaemic heart disease (IHD) were more likely to receive vaccine than those without it (odds ratio $(\mathrm{OR})=8.44$ (95\% confidence interval (95\% CI 1.04 to 68.03$))$, as were patients with chronic pulmonary disease $(\mathrm{OR}=6.18$ (95\% CI 1.34 to 28.47)), and patients receiving corticosteroids $(\mathrm{OR}=5.13(95 \%$ CI 1.10 to 23.95$))$. Neither use of DMARDs, nor the presence of RF influenced uptake of the influenza vaccine $(\mathrm{OR}=0.45(95 \% \mathrm{CI} 0.14$ to 1.50$))$, and $(\mathrm{OR}=1.62(95 \% \mathrm{CI}$ 0.75 to 3.51$)$, respectively).

This study relied on patient's recall about whether they had been vaccinated or not, and this was a potential source of inaccuracy.

The uptake of influenza vaccination in patients with RA taking MTX in this study was $56 \%$, and we consider this result to be suboptimal. The principal reason for this seems not to be a lack of awareness of the need for vaccination by the patient, but the fact that they have not been offered it. Hospital doctors and rheumatology nurses at present do not seem to be identifying such patients in large numbers, with most vaccinees being identified by their primary care doctor. Secondary care professionals could also deal with patient concerns over the efficacy and safety of such vaccines, which are influencing $24 \%$ of non-vaccinees.

In conclusion, this study shows that uptake of influenza vaccine in patients with RA taking MTX is suboptimal. Reasons for the shortfall are patient concerns over side effects, beliefs of vaccine inefficacy, and the fact that the patients are not being offered the vaccine in the first place. We believe that secondary care has a role in allaying patient concerns and improve adherence to BSR guidelines.

\section{Authors' affiliations \\ M J Bridges, C A Kelly, J Hamilton, C Heycock, Queen Elizabeth Hospital, Sheriff Hill, Gateshead, Tyne and Wear NE9 6SX, UK \\ D Coady, Freeman Hospital, High Heaton, Newcastle-on-Tyne, Tyne and Wear NE7 7DN, UK \\ Correspondence to: Dr M J Bridges, Department of Rheumatology, James Cook University Hospital, Marton Road, Middlesborough TS4 3BW, UK; drmattbridges@hotmail.com \\ Accepted 8 December 2002 \\ REFERENCE \\ 1 BSR. National guidelines for the monitoring of second line drugs. London: British Society for Rheumatology, 2000.}




\title{
Hepatitis B reactivation in a chronic hepatitis B surface antigen carrier with rheumatoid arthritis treated with infliximab and low dose methotrexate
}

\author{
P Ostuni, C Botsios, L Punzi, P Sfriso, S Todesco
}

Ann Rheum Dis 2003;62:686-687

\begin{abstract}
nfliximab, a humanised, mouse derived, genetically engineered, monoclonal antibody to tumour necrosis factor $\alpha$ ( $\mathrm{TNF} \alpha)$, is successfully used in association with low dose methotrexate in the treatment of rheumatoid arthritis (RA). ${ }^{1}$ Serious infections have been reported to be associated with infliximab treatment. ${ }^{12}$ However, the safety of infliximab is unknown or has not been yet established in chronic viral infections, including human immunodeficiency virus, hepatitis $\mathrm{B}$ virus ( $\mathrm{HBV}$ ) or hepatitis $\mathrm{C}$ virus infections. We describe a case, from our cohort of 102 patients treated with infliximab plus methotrexate, who carried hepatitis B surface antigen (HBsAg) and subsequently developed acute hepatitis due to HBV reactivation after 16 months of treatment with infliximab.
\end{abstract}

\section{CASE REPORT}

A 49 year old man was diagnosed as having RA in January 1990. HBsAg, and HBe and HBc antibodies were positive, while HBe antigen and HBs antibodies were negative. From January 1990 to May 2000 he received several treatments consisting of different disease modifying antirheumatic drugs (DMARDs) (hydroxychloroquine, sulfasalazine, sodium aurothiomalate, and cyclosporin A) in addition to oral steroids $(<10 \mathrm{mg} /$ day of prednisone $)$ and non-steroidal antiinflammatory drugs. Serum aspartate aminotransferase (AST) and alanine aminotransferase (ALT) remained persistently normal. However, response to these treatments was poor, and peripheral arthritis persisted. In June 2000 he began treatment with infliximab ( $6 \mathrm{mg} / \mathrm{kg}$ every eight weeks) associated with methotrexate ( $10 \mathrm{mg} /$ week), with a good response of the joint signs and symptoms, as well as the inflammatory indices. In January 2002 he developed malaise, anorexia, fatigue, increased levels of AST (97 IU/1) and ALT (176 IU/1), and then he was admitted to our division.

Hepatomegaly was evident on the physical examination. Serum AST, ALT, and total bilirubin were further raised to 336 $\mathrm{IU} / \mathrm{l}, 573 \mathrm{IU} / \mathrm{l}$, and $22.6 \mu \mathrm{mol} / \mathrm{l}$, respectively. Hypoalbuminaemia and prolongation of the prothrombin time were also found. Abdominal ultrasonography showed ascites. There was no evidence of hepatitis A and C virus, Epstein-Barr virus, cytomegalovirus, or herpes simplex virus infection. IgM HBC antibodies, and high serum HBV/DNA polymerase levels ( $1492 \mathrm{pg} / \mathrm{ml}$ ) were detected, and acute hepatitis caused by $\mathrm{HBV}$ reactivation was diagnosed. Infliximab and methotrexate were stopped, while prednisone $(8 \mathrm{mg} /$ day) was continued. Lamivudine at a daily dose of $100 \mathrm{mg}$ was started, and, after two months, serum AST and ALT returned to normal ( 30 and $40 \mathrm{IU} / \mathrm{l}$, respectively) and HBV/DNA polymerase levels dropped (9 pg/ml).

\section{DISCUSSION}

Hepatitis B reactivation is a well known adverse event in patients with chronic HBV infection receiving cytotoxic or immunosuppressive treatment . ${ }^{3}$

Inhibition of TNF $\alpha$ might lead to additional advantages for viral replication owing to escape from host antiviral mechanisms. The antiviral activity of TNF $\alpha$ has long been recognised. ${ }^{4}$ Indeed, synergistic activity of interferon $\gamma($ INF $\gamma)$ and TNF $\alpha$ has been shown to affect early steps in herpes simplex virus replication at the level of early gene transcription and translation, ${ }^{5}$ while these cytokines inhibit murine cytomegalovirus late gene transcription and DNA replication. ${ }^{6}$

Data from animal models indicate that INF $\gamma$ and TNF $\alpha$ may also synergistically inhibit HBV gene expression and replication, leading to a reduction in the intracellular level of HBV transcripts. ${ }^{78}$ Moreover, TNF $\alpha$, which is induced by HBV antigens, is supposed to be beneficial for viral clearance. ${ }^{9}$ On the other hand, methotrexate might reduce the clearance of intrahepatic HBV depleting specific cytotoxic cells. ${ }^{10}$

Despite the wide use of methotrexate in the treatment of RA and the high prevalence of HBV infections in some countries, to our knowledge, only two other cases ${ }^{11} 12$ with fulminant hepatitis B (precore variant mutant type) after two years' treatment and concomitant discontinuation of methotrexate have been reported.

So far, no reports have described an association between HBV hepatitis and conventional DMARDs such as D-penicillamine or sulfasalazine. Instead, a case with both Crohn's disease and ongoing active hepatitis $\mathrm{C}$ infection has been reported. The patient underwent infliximab treatment with no worsening of his liver function or polymerase chain reaction status during a 16 week follow up period. ${ }^{13}$

Our case suggests that serological assay for hepatitis B should be performed before treatment with infliximab. If immunosuppressant drugs must be used in patients with RA and chronic infection with HBV, then liver function and HBV/ DNA polymerase levels should be closely monitored.

\section{Authors' affiliations}

P Ostuni, C Botsios, L Punzi, P Sfriso, S Todesco, Division of Rheumatology, Department of Medical and Surgical Sciences, School of Medicine, University of Padua Italy

Correspondence to: Dr P Sfriso, Division of Rheumatology, via Giustiniani 2, 35128 , Padova Italy; paolo.sfriso@unipd.it

Accepted 19 December 2002

\section{REFERENCES}

1 Lipsky PE, van der Heijde DM, St Clair EW, Furst DE, Breedveld FC, Kalden JR, et al. Infliximab and methotrexate in the treatment of rheumatoid arthritis. Anti-Tumor Necrosis Factor Trial in Rheumatoid Arthritis with Concomitant Therapy Study Group. N Engl J Med 2000:343: 1594-602.

2 Keane J, Gershon S, Wise RP, Mirabile-Levens E, Kasznica J, Schwieterman WD, et al. Tuberculosis associated with infliximab, a tumor necrosis factor alpha neutralizing agent. $N$ Engl J Med 2001;345:1098-104.

3 Yeo W, Chan PK, Zhong S, Ho WM, Steinberg JL, Tam JS, et al. Frequency of hepatitis $B$ virus reactivation in cancer patients undergoing cytotoxic chemotherapy: a prospective study of 626 patients with identification of risk factors. J Med Virol 2000;62:299-307.

4 Wong GH, Goeddel DV. Tumour necrosis factors alpha and beta inhibit virus replication and synergize with interferons. Nature 1986;323:819-22. 
5 Feduchi E, Alonso MA, Carrasco L. Human gamma interferon and tumor necrosis factor exert a synergistic blockade on the replication of herpes simplex virus. J Virol 1989;63:1354-9

6 Lucin P, Jonjic S, Messerle M, Polic B, Hengel H, Koszinowski UH. Late phase inhibition of murine cytomegalovirus replication by synergistic action of interferon-gamma and tumour necrosis factor. J Gen Virol 1994:75:101-10.

7 Guidotti LG, Ishikawa T, Hobbs MV, Matzke B, Schreiber R, Chisari FV Intracellular inactivation of the hepatitis $B$ virus by cytotoxic $T$ lymphocytes. Immunity 1996:4:25-36.

8 Pasquetto V, Wieland S, Uprichard S, Tripodi M, Chisari F. Cytokine-sensitive replication of hepatitis $B$ virus in immortalized mouse hepatocyte cultures. J Virol 2002;76:5646-53.

9 Schlaak JF, Tully G, Löhr HF, Gerken G, Meyer Zum Büschenfelde KH. $\mathrm{HBV}$-specific immune defect in chronic hepatitis $\mathrm{B}$ is correlated with a dysregulation of pro-and anti-inflammatory cytokines. Clin Exp Immunol 1999; 1 15:508-14.

10 Cronstein BN. Molecular therapeutics. Methotrexate and its mechanism of action. Arthritis Rheum 1996:39:1951-60.

11 Narvaez J, Rodriguez-Moreno J, Martinez-Aguila MD, Clavaguera MT. Severe hepatitis linked to $B$ virus infection after withdrawal of low dose methotrexate therapy. J Rheumatol 1998:25:2037-8.

12 Ito S, Nakazono K, Murasawa A, Mita Y, Hata K, Saito N, et al. Development of fulminant hepatitis $B$ (precore variant mutant type) after the discontinuation of low-dose methotrexate therapy in a rheumatoid arthritis patient. Arthritis Rheum 2001;44:339-42.

13 Campbell S, Ghosh S. Infliximab therapy for Crohn's disease in the presence of chronic hepatitis C infection. Eur J Gastroenterol Hepatol 2001;13:191-2.

\title{
Anticardiolipin antibodies in acute multifocal posterior placoid pigment epitheliopathy
}

\author{
I Uthman, D M Naijar, S S Kanj, Z Bashshur
}

Ann Rheum Dis 2003;62:687-688

A cute multifocal posterior placoid pigment epitheliopathy (AMPPPE) is a disorder of otherwise healthy young adults. A possible thrombotic process involving the choroid has been suggested in the pathogenesis of this condition. We report a case of AMPPPE and anticardiolipin antibodies ( $\mathrm{aCL}$ ).

\section{CASE REPORT}

A 32 year old woman presented because of sudden onset of bilateral decrease in visual acuity. Her past medical history was negative. One week before the decrease in vision, the patient had been complaining of headaches associated with fever, chills, and a rash on her neck and lower extremities.

The initial ocular examination showed a visual acuity of $20 / 200$ in the right eye and 20/30 in the left eye. Fundus examination disclosed bilateral multiple yellow-white placoid lesions in the posterior pole at the level of the retinal pigment epithelium (RPE). Serous detachment of the right macula was also noted. Fluorescein angiography showed early hypofluorescence of the lesions with staining in the late phases of the angiogram. Based on the clinical and fluorescein angiogram findings, the diagnosis of AMPPPE was made.

Physical examination showed a temperature of $38.5^{\circ} \mathrm{C}$, tender posterior cervical lymphadenopathy, as well as skin lesions affecting both legs. Biopsy of the lesions was compatible with erythema nodosum. Extensive fever investigation was negative. The erythrocyte sedimentation rate was $69 \mathrm{~mm} / \mathrm{lst} \mathrm{h}$, and IgG aCL was 78 GPL (normal <15.0 GPL); IgM aCL was negative.

Over a period of two weeks, the fever resolved and the patient's vision started to improve without any treatment. The fundus lesions disappeared leaving irregular RPE pigmentation. One month later her vision had recovered to 20/30 in the right eye and 20/25 in the left eye. There was total resolution of the serous detachment in the right eye. Two, four, and six months after presentation, the IgG aCL were 63, 57, and 52 GPL, respectively. One year later, the aCL titres were normal. The eye and systemic examination remained normal throughout this period.

\section{DISCUSSION}

AMPPPE has been associated with a wide variety of disorders, including viral infections (adenovirus), streptococcal infections, vasculitides (cerebral vasculitis and Wegener's granulo- matosis), post-hepatitis B vaccination, Lyme disease, tuberculosis, and sarcoidosis. ${ }^{1-3}$ Few reports have suggested an immunological mechanism.

The pathogenesis of AMPPPE remains obscure. ${ }^{4}$ AMPPPE has been associated with retinal vascular occlusive disease. Charteris et al reported a case of AMPPPE complicated by a central retinal vein occlusion. ${ }^{5}$ The occurrence of these two conditions at the same time may imply that AMPPPE is part of a wider thrombotic disease. Furthermore, the presence of a serous macular detachment further supports injury to the choriocapillaris and RPE. Serous macular and retinal detachment are often seen in occlusive diseases of the choriocapillaris (for example, toxaemia of pregnancy, disseminated intravascular coagulopathy). ${ }^{6}$

Antiphospholipid antibodies (aPL) have been reported in various ophthalmological conditions, including amaurosis fugax, retinal arterial and venous occlusion, and transient diplopia as well as in recurrent ischaemic optic neuropathy. ${ }^{7}$ They have not been previously described in association with AMPPPE. The aPL have been frequently detected in patients with various infectious diseases. ${ }^{8}$ Although aPL associated with infections were initially thought to be non-pathogenic and not associated with thrombotic complications, ${ }^{8}$ recent data uncovered a possible pathogenic role for these antibodies in precipitating thrombosis. ${ }^{8}$ Lupus anticoagulant or aCL, or both, were associated with a number of viral infections like hepatitis $C$ virus, human immunodeficiency virus, cytomegalovirus, varicella zoster, Epstein B virus, adenovirus, and parvovirus B. In many instances the presence of these antibodies was associated with thrombosis. ${ }^{8}$

The presentation and course of our patient suggest a possible role for aCL in the pathogenesis of AMPPPE.

\section{Authors' affiliations}

I Uthman, S S Kani, Department of Internal Medicine, American University of Beirut, Beirut, Lebanon

D M Naijar, Z Bashshur, Department of Ophthalmology, American University of Beirut, Beirut, Lebanon

Correspondence to: Dr Z Bashshur, American University of Beirut Medical Centre, PO Box 113-6044, Beirut, Lebanon; zb00@aub.edu.lb

Accepted 30 November 2002 


\author{
REFERENCES \\ 1 Lowder CY, Foster RE, Gordon SM, Gutman FA. Acute posterior \\ multifocal placoid pigment epitheliopathy after acute group A \\ streptococcal infection. Am J Ophthalmol 1996;122:115-17. \\ 2 Chiquet C, Lumbroso L, Denis P, Papo T, Durieu I, Lehoang P. Acute \\ posterior multifocal placoid pigment epitheliopathy associated with \\ Wegener's granulomatosis. Retina 1999;19:309-13. \\ 3 Brezin AP, Massin-Korobelnik P, Boudin M, Gaudric A, Lettoang P. \\ Acute posterior multifocal placoid pigment epitheliopathy after hepatitis $B$ \\ vaccine. Arch Ophthalmol 1995; 113:297-300 \\ 4 Gass JDM. Acute posterior multifocal placoid pigment epitheliopathy. \\ Arch Ophthalmol 1968;80:177-85
}

5 Charteris DG, Khanna V, Dhillon B. Acute posterior multifocal placoid pigment epitheliopathy complicated by central retinal vein occlusion. $\mathrm{Br} J$ Ophthalmol 1989;73:765-8.

6 Ghazi NG, Gollance SA, Green WR. Choroidal vascular occlusion in a child with a connective tissue disease and complement $\mathrm{C} 4$ deficiency. Ophthalmology 2002; 109:1272-7.

7 Kleiner RC, Najarian LV, Schatten S, Jabs DA, Patz A, Kaplan HJ.

Vaso-occlusive retinopathy associated with antiphospholipid antibodies (lupus anticoagulant retinopathy). Ophthalmology 1989:96:896-904

8 Uthman I, Gharavi AE. Viral infections and antiphospholipid antibodies. Semin Arthritis Rheum 2002;31:256-63.

\title{
Multifocal lymphadenopathy associated with severe Kawasaki disease: a difficult diagnosis
}

\author{
F Falcini, G Simonini, G Battista Calabri, R Cimaz
}

Ann Rheum Dis 2003;62:688-689

\section{CASE REPORT}

A previously healthy $3 \frac{1}{2}$ month old infant was admitted to the hospital with dyspnoea, malaise, and irritability in August 2001. One week before he had had an upper respiratory infection treated with amoxycillin and inhaled steroids; the day before admission he presented high grade (up to $40^{\circ} \mathrm{C}$ ) temperature.

On admission he was febrile $\left(39^{\circ} \mathrm{C}\right)$, pale, restless; his respiratory rate was $50 / \mathrm{min}$ and pulse 120 beats/min. Clinical evaluation showed oral cyanosis, redness of the pharynx, and bilateral suppurative conjunctivitis. A chest radiograph showed pulmonary infiltrates in the right lung.

Electrocardiography (ECG) and echo colour Doppler excluded cardiac abnormalities. An electroencephalogram showed diffuse slow waves. A lumbar puncture was performed to exclude a meningeal infection; the cerebrospinal fluid was clear with normal glucose and protein levels and a mild increase in mononuclear cells.

Blood tests showed: erythrocyte sedimentation rate (ESR) (Westergren) $120 \mathrm{~mm} / \mathrm{lst} \mathrm{h}, \mathrm{C}$ reactive protein (CRP) 221 $\mathrm{mg} / \mathrm{l}$, white blood cells $16.8 \times 10^{9} / 1$ (neutrophils $75.2 \%$ ), haemoglobin $94 \mathrm{~g} / \mathrm{l}$, and platelet count $504 \times 10^{9} / \mathrm{l}$. Serum urea, creatinine, electrolytes, transaminases, $\gamma$-glutamyltransaminase, IgA, IgM, IgG, lactate, pyruvate, lactate dehydrogenase levels, and blood and urine cultures were normal. Serological tests for antibodies to measles, mumps, chickenpox, herpes viruses, adenovirus, HIV, hepatitis $\mathrm{C}$ and $\mathrm{B}$, cytomegalovirus, Mycoplasma pneumoniae, Leishmania were all negative. Vanillylmandelic acid in the urine was in the normal range.

Despite wide spectrum antibiotic treatment (netilmicin, ceftazidime) his general condition deteriorated and he was less alert and extremely pale. He lost weight and developed liver, spleen, and cervical lymph node enlargement.

On day 5 from admission, a diffuse maculopapular rash affecting all the body and the scalp was evident. Over the following days the child had diarrhoea and developed generalised oedema. Fever persisted (up to $39.5^{\circ} \mathrm{C}$ ).

Abdominal ultrasound confirmed hepatosplenomegaly and excluded the presence of other masses. Cardiac evaluation, with ECG and echocardiography performed on days 7 and 10 was normal.

Blood tests were repeated and showed an increased ESR (132 mm/lst h) and CRP (231 mg/ll), and decreased haemoglobin $(60 \mathrm{~g} / \mathrm{l})$, fibrinogen $4.5 \mathrm{~g} / \mathrm{l}$, and platelet count $116 \times 10^{9} /$. After blood transfusion, the child underwent abdominal and chest computed tomographic scan that showed the presence of multiple lymph nodes in the retroperitoneal, cervical, and axillar areas.

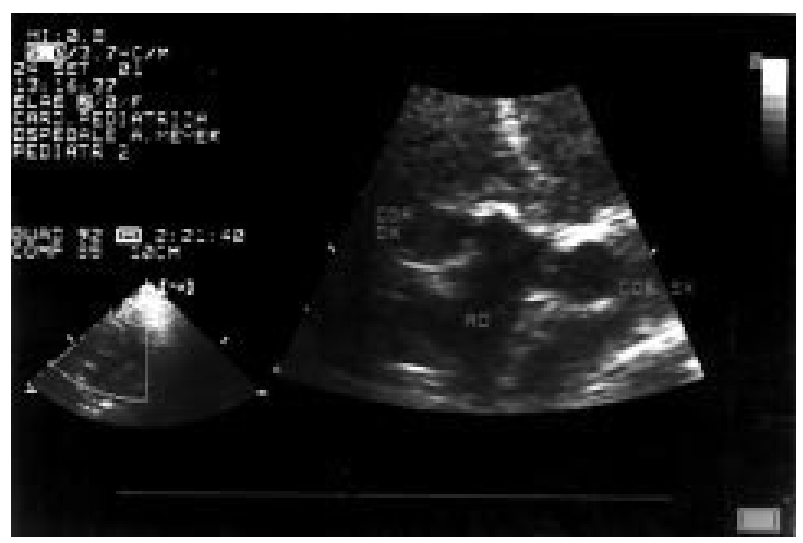

Figure 1 Giant aneurysms. The left coronary diameter was $13 \mathrm{~mm}$ and the right coronary diameter $11 \mathrm{~mm}$. Apical five chambers view modified for coronary arteries.

Lung infiltrates were still present. As a peripheral blood smear showed the presence of myelocytes and promyelocytes a bone aspiration was performed, and several histiocytes were found. Because a lymphoproliferative disorder was suspected a bone marrow biopsy was planned. During anaesthesia the boy underwent cardiac arrest and was transferred to the intensive care unit.

ECG showed inverted T waves and echo colour Doppler two giant aneurysms: the left coronary diameter was $13 \mathrm{~mm}$ and the right coronary diameter $11 \mathrm{~mm}$ (fig 1); on the posterior left ventricular wall a small area of myocardial necrosis was detected.

The child was then referred to our unit. Kawasaki disease (KD) was then suspected and the appropriate treatment with intravenous immunoglobulin (IVIg) $(2 \mathrm{~g} / \mathrm{kg})$ was immediately given. Anticoagulation with low weight heparin was also started, owing the appearance of giant aneurisms and myocardial infarction. The fever promptly dropped during IVIg infusion, so high dose aspirin was not started. The patient improved dramatically; he became alert and active.

Blood tests showed a high platelet count $1.2 \times 10^{12} /$. Three weeks after admission the patient's two digits of his right hand peeled. Blood tests progressively improved and completely normalised over four weeks. In October the child was discharged in general good condition while continuing to receive treatment with oral anticoagulant. At the last control, 
May 2002, a cardiological evaluation showed a slight reduction of the coronary aneurysms (left coronary diameter $9 \mathrm{~mm}$ and right $10 \mathrm{~mm}$ ), and anticoagulation was continued.

\section{DISCUSSION}

$\mathrm{KD}$ is one of the most common systemic vasculitides in childhood. Owing to a lack of diagnostic tests, the diagnosis is based on clinical criteria after the exclusion of other febrile diseases in young children. ${ }^{1}$

The presence of histiocytes, probably a reactive event, led us to consider the diagnosis of histiocytosis. The differential diagnosis includes sepsis, scarlet fever, toxic shock syndrome, viral infections, in particular due to enterovirus, adenovirus, measles, parvovirus, cytomegalovirus, Epstein-Barr virus, and Mycoplasma pneumoniae ${ }^{2}$. Lymphoproliferative disorders are usually not included in the differential diagnosis of KD.

In fact, recently an increasing number of children with atypical onset of $\mathrm{KD}$ have been reported, ${ }^{3-5}$ but to our knowledge a patient with clinical signs mimicking a lymphoproliferative disorder has not been described so far.

This case emphasises that KD must be suspected in any child with high, persistent fever, even in absence of all diagnostic criteria; IVIg can be recommended before the typical manifestations are all present. ${ }^{6}$ Delayed treatment might be responsible for severe coronary complications, and even sudden death, especially in infants. ${ }^{7}$

\section{Authors' affiliations}

F Falcini, G Simonini, Rheumatology Unit, Department of Paediatrics, University of Florence, Italy

G Battista Calabri, Paediatric Cardiology Unit, A Meyer Children

Hospital, Florence, Italy

R Cimaz, Istituti Clinici di Perfezionamento, Milan, Italy

Correspondence to: Dr F Falcini, Department of Paediatrics, Rheumatology Unit, Via Pico della Mirandola 24, 50132 Florence, Italy; falcini@unifi.it

Accepted 30 November 2002

\section{REFERENCES}

1 Anonymous. Diagnostic guidelines for Kawasaki disease. Circulation 2001; 103:335-6.

2 Petty RE, Cassidy JT. Kawasaki disease. In: Cassidy JT, Petty RE, eds. Textbook of pediatric rheumatology. 4th ed. Philadelphia: Saunders, 2001:580-94.

3 Rowley AH, Gonzales Crussi F, Gidding SS, Duffy CE, Shulman ST. Incomplete Kawasaki disease with coronary artery involvement. J Pediatr 1987; 1 10:409-13.

4 Rowley AH. Incomplete (atypical) Kawasaki disease. Paediatr Infect Dis J 2002;21:563-5.

5 Witt MT, Minich LA, Bohnsack JF, Young PC. Kawasaki disease: more patients are being diagnosed who do not meet American Heart Association criteria. Pediatrics 1999;104:10.

6 Newburger JW. Kawasaki disease. Current treatment options. Cardiovasc Med 2000;2:227-32.

7 Oki I, Tanihara S, Ojima T, Nakamura Y, Yanagawa H. A multicenter collaborative study on the risk factors of cardiac sequelae due to Kawasaki disease: a one-year follow-up study. Acta Pediatr 2000;89: 1435-8.

\section{Brain abscess in rheumatoid arthritis}

\section{C-S Lee, C-K Chang}

\section{CASE REPORT}

A 62 year old man had RA for five years that had been diagnosed according to the 1987 American Rheumatic Association criteria. His disease was well controlled with disease modifying antirheumatic agents (DMARDs). However, the DMARDs were discontinued in March 2000, and he entered a leflunomide clinical trial from April 2000 to August 2000. He improved during the trial. After the trial ended and the leflunomide was discontinued, his joint pain and swelling resumed, so DMARDs were started again.

In December 2000, he arrived in our emergency department with the sudden onset of a disturbance of consciousness, fever, chills, throbbing headache, and left limb weakness for a few days. On physical examination, his temperature was $38.3^{\circ} \mathrm{C}$, and he had slurred speech, isochoric pupils, a supple neck, and muscle power in all four extremities grade $3 / 5$. However he then had a seizure. Emergency computed tomographic (CT) scanning showed decreased lucency in the right mastoid air cells and a lesion suggestive of a focal infarct or cerebritis affecting the lower part of the right posterior frontal lobe (fig 1). A lumbar puncture was performed with an opening pressure of 240 $\mathrm{cm} \mathrm{H}_{2} \mathrm{O}$ and a closing pressure of $210 \mathrm{~cm} \mathrm{H}_{2} \mathrm{O}$. The cerebrospinal fluid (CSF) was clear and he had a white blood cell (WBC) count of $8730 / \mathrm{ml}$ with $60 \%$ neutrophils and $37 \%$ lymphocytes.

The Pandy test was positive, protein 150 (10-45) mg/day. Microbiological investigations (antigens and/or culture) were all negative, as were blood cultures for bacteria and fungi. Penicillin and chloramphenicol were given but did not improve his condition. Phenytoin was also given for seizure control. Ten days after admission, magnetic resonance imaging (MRI) showed focal cerebritis with possible abscess formation in the right frontal and temporal lobes and the right insular cortex and a

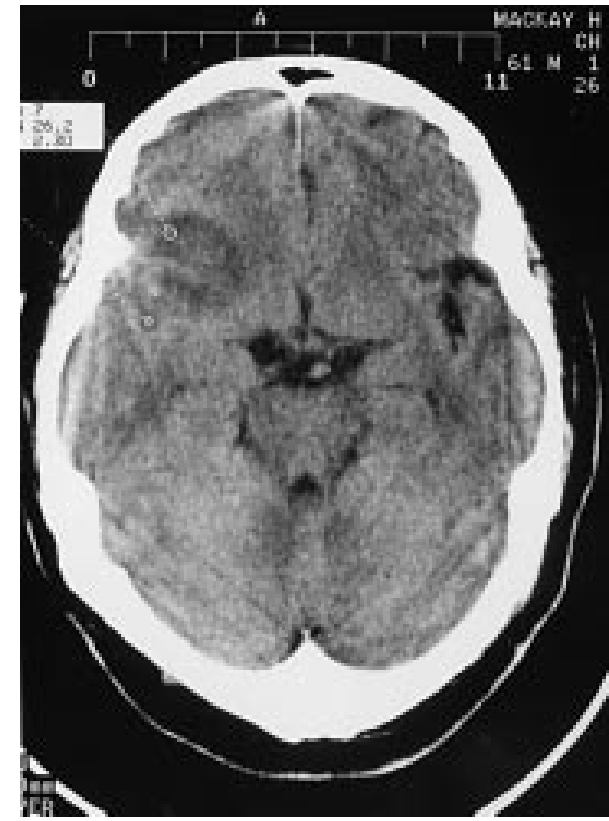

Figure 1 CT scan of the brain shows an ill defined hypodense area in the right frontotemporal junction.

portion of the right basal ganglion (TR 2500/TE 100) (fig 2). A right frontotemporal craniotomy was performed to drain the abscess. The pathology report was consistent with an abscess, 


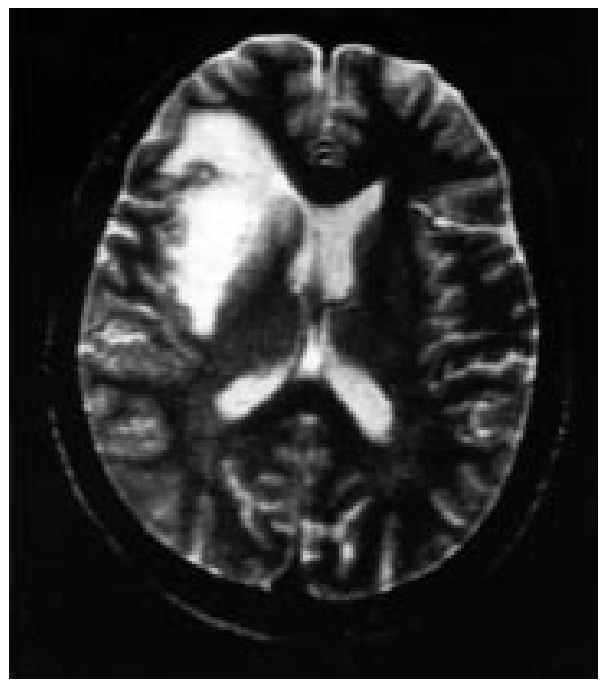

Figure 2 MRI of the brain shows high signal intensity over the right frontotemporal junction and right insular cortex and a portion of the right basal ganglion on $\mathrm{T}_{2} \mathrm{~W}_{1}$.

noting purulent exudate with granulation tissue, an accumulation of foamy cells, and reactive gliosis in adjacent brain tissue. No micro-organisms were identified. The antibiotics were changed to ceftriaxone, metronidazole, chloramphenicol, and vancomycin. The patient's mental status became clear and he gradually regained muscle power.

\section{DISCUSSION}

Our case demonstrates that brain abscess should be suspected in immunocompromised patients, such as those with RA, who present with headache, fever, change in consciousness, and seizure. The diagnosis of cerebral abscess would have been delayed in our patient if a CT scan or MRI had not been done.

The non-specific symptoms and signs of brain abscess (fever, headache, focal neurological deficits) may lead to diagnostic delay, as was the case with our patient. We were unable to identify a micro-organism, either by bacteriology, serology, or pathology. This might have been due to the early use of empirical parenteral antibiotic treatment. The patient might have had impaired immunity secondary to his underlying RA or, possibly, the leflunomide trial he had previously participated in, or both. Leflunomide has a long half life of about two weeks, ${ }^{1}$ but he did not present with the brain abscess until four months after the end of the trial. We did not check the serum leflunomide level during the admission for the abscess. We have found no reported cases of patients with RA developing brain abscess while being treated with leflunomide, hydroxychloroquine, sulfasalazine, or methotrexate.

\section{Authors' affiliations}

C-S Lee, Division of Allergy Immunology, and Rheumatology, Department of Internal Medicine, Mackay Memorial Hospital, Taipei, Taiwan; Taipei Medical University, Taipei, Taiwan; and Mackay Junior College of Nursing, Taipei, Taiwan

C-K Chang, Department of Neurosurgery, Mackay Memorial Hospital Taipei, Taiwan

Correspondence to: Dr Chyou-Shen Lee, 5F, No 1, Alley 8, Lane 554, Pei-Ann Road, Taipei, Taiwan; amy@ms2.mmh.org.tw

Accepted 16 December 2002

\section{REFERENCE}

1 Prakash A, Jarvis B. Leflunomide: a review of it use in active rheumatoid arthritis. Drugs 1999;58:1137-64.

\title{
Overlap connective tissue disease, pulmonary fibrosis, and extensive subcutaneous calcification
}

\author{
A T Y Chan, B P Wordsworth, J McNally
}

Ann Rheum Dis 2003;62:690-691

S ubcutaneous calcification is a common late feature of childhood dermatomyositis, ${ }^{1}$ but is rare as a presentation of adult onset dermatomyositis. ${ }^{2}$ It has been reported in scleroderma ${ }^{3}$ and systemic lupus erythematosus (SLE) ${ }^{4}$ However, extensive subcutaneous calcification in overlap connective tissue disease is rare. ${ }^{5}$ We describe two patients who had pulmonary fibrosis and extensive subcutaneous calcification of the buttocks in the same sequence as part of an overlap connective tissue disease.

\section{CASE REPORTS}

\section{Case 1}

A 28 year old woman presented in July 1994 with Gottron's papules over the proximal interphalangeal (PIP) and metacarpophalangeal (MCP) joints associated with muscle tenderness over her arms and thighs. In addition, she had a butterfly rash overlying her face, alopecia, oral ulcers, and Raynaud's phenomenon. She also had arthritis of her PIP, knee, and ankle joints. Laboratory tests showed: haemoglobin 122 g/l; lympho- penia $0.77 \times 10^{9} /$; erythrocyte sedimentation rate (ESR) 31 $\mathrm{mm} / \mathrm{lst} \mathrm{h}$; C reactive protein $(\mathrm{CRP})<6 \mathrm{mg} /$; creatine kinase (CK) normal; antinuclear antibody 1/160 titre with a speckled pattern. Her other autoantibodies (anti-Jo-1, anti-Scl-70, anticentromere, anti-UIRNP, and double stranded DNA) were negative. Skin biopsy showed degeneration of the basal cell layer with vacuolar changes and a mononuclear cell infiltrate in the upper dermis. Electromyography of the deltoids showed low amplitude, short duration polyphasic potentials consistent with a myopathic process. A diagnosis of overlap connective tissue disease was made as the patient displayed features of both dermatomyositis and SLE.

A year later she developed shortness of breath, and a high resolution computed tomography (HRCT) scan of the lung disclosed basal fibrosis with areas of ground glass shadowing. Treatment was started with prednisolone $60 \mathrm{mg}$ once a day, and her pulmonary function improved markedly.

In June 1999, five years after presentation, she complained of left buttock pain. Pelvic radiographs showed marked 


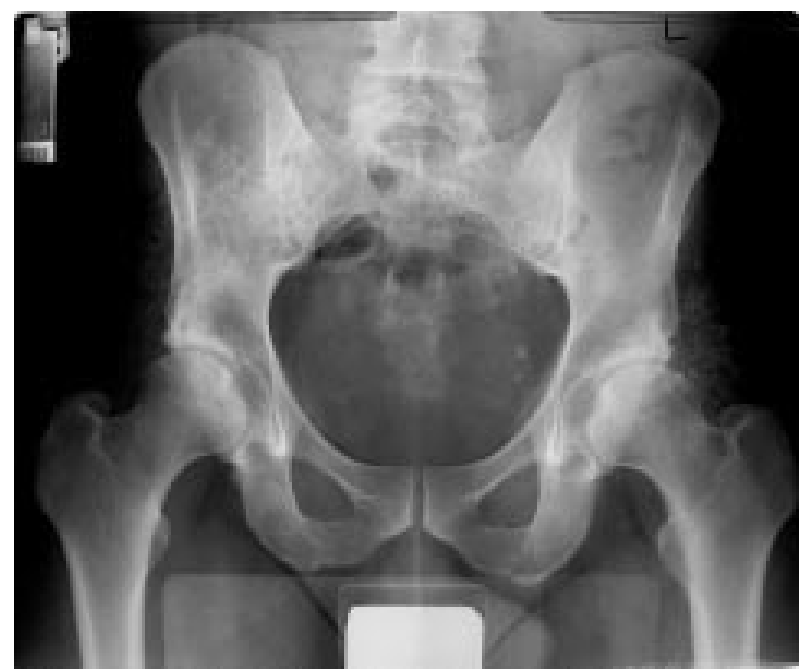

Figure 1 Extensive subcutaneous calcification most marked around the left iliac wing.

subcutaneous calcification around the left hip area $(3 \times 1 \mathrm{~cm})$. This restricted movement around the left hip but was not severe enough to warrant surgical excision.

\section{Case 2}

A 35 year old man presented in October 1996 with a nine month history of arthralgia, alopecia, photosensitive rash, and Raynaud's phenomenon. On examination he had arthritis of the MCP joints, wrists, shoulders, knees, and ankles. His hands had the typical appearance of scleroderma with nailfold infarcts and dilated capillary loops seen on capillaroscopy. Positive laboratory findings were as follows: haemoglobin $100 \mathrm{~g} / \mathrm{l}$; lymphopenia $0.8 \times 10^{9} / \mathrm{l}$; ESR $62 \mathrm{~mm} / \mathrm{lst} \mathrm{h}$; CRP $<6 \mathrm{mg} / \mathrm{l}$; CK normal; antinuclear antibody $1 / 320$ titre with a homogenous pattern. His other autoantibodies (anti-Jo-1, anti-Scl-70, anticentromere, anti-UIRNP, and double stranded DNA antibodies) were negative. A diagnosis of overlap connective tissue disease was made as the patient displayed features of both SLE and scleroderma.

A year later he developed acute dyspnoea. An HRCT scan of the lung showed pulmonary fibrosis. Transbronchial biopsy revealed pulmonary fibrosis with a lymphocytic infiltrate. Prednisolone was started and he was also given intravenous cyclophosphamide.

In October 1999, three years after the initial presentation, he complained of left buttock pain. Examination showed a $10 \times 8 \mathrm{~cm}$ solid mass in the left buttock, fixed to skin and muscle and tender to palpation (fig 1). This markedly limited movement in the left hip. These painful dystrophic calcifications were removed surgically, with a rapid and marked improvement in his symptoms and mobility.

\section{DISCUSSION}

The pattern of pulmonary fibrosis and extensive subcutaneous buttock calcification in both our cases may be seen in overlap connective tissue disease. Itoh et al described a 38 year old woman with mixed connective tissue disease who had painful subcutaneous calcification in her buttocks, and pulmonary hypertension. $^{6}$ The sequence of events and pattern of calcification were similar to our cases.

The predisposition to calcification in the buttock area may be due to local tissue damage and pressure necrosis. Dystrophic calcification occurs as a result of local tissue injury and inflammation. Tissue necrosis may increase alkalinity, which may cause calcium precipitation. ${ }^{5}$ Panniculitis, which occurs in connective tissue disease, is precipitated by local trauma to subcutaneous fat and leads to dystrophic calcification. ${ }^{7}$

Further studies are required to evaluate the use of medical treatments (diltiazem, warfarin, aluminium hydroxide, and colchicine) in subcutaneous calcification. We suggest that surgical excision be considered in patients with disabling extensive subcutaneous calcification (as in case 2 ).

\section{Authors' affiliations}

A T Y Chan, J McNally, Department of Rheumatology, Battle Hospital Oxford Road, Reading RG30 IAG, UK

B P Wordsworth, Musculoskeletal Research Unit, Nuffield Orthopaedic Centre, Windmill Road, Headington, Oxford OX3 7LD, UK

Correspondence to: Dr A T Y Chan; antonichan@hotmail.com

Accepted 13 November 2002

\section{REFERENCES}

1 Blane CE, White SJ, Braunstein EM, Bowyer SL, Sullivan DB. Patterns of calcification in childhood dermatomyositis. AJR Am J Roentgenol 1984; 142:397-400.

2 Cohen MG, Nash P, Webb J. Calcification is rare in adult-onset dermatopolymyositis. Clin Rheumatol 1986;5:512-16

3 Veerapen K, Watt I, Dieppe P. Severe subcutaneous calcification in the CREST syndrome: evidence of high turnover of calcific deposits. $\mathrm{Br} J$ Rheumatol 1987;26:89-92.

4 Minami A, Suda K, Kaneda K, Kumakiri M. Extensive subcutaneous calcification of the forearm in SLE. J Hand Surg 1994;19:638-41.

5 Walsh JS, Fairley JA. Calcifying disorders of the skin. J Am Acad Dermatol 1995;33:693-706.

6 Itoh O, Nishimaki T, Itoh M, Ohira H, Irisawa A, Kaise S, et al. Mixed connective tissue disease with severe pulmonary hypertension and extensive subcutaneous calcification. Intern Med 1998;37:421-5.

7 Requena L, Yus ES. Panniculitis. Part II. Mostly lobular panniculitis. J Am Acad Dermatol 2001;45:325-61.

\section{Early descriptions of Adamantiades-Behçet's disease}

\section{C Zouboulis, P Kaklamanis}

A fter the publication of an article on "Behçet's disease and thrombophilia" by Leiba et al, ${ }^{1}$ Ehrlich $^{2}$ and Leiba $e t$ $a^{3}$ discussed descriptions of the disease before Behçet. They agreed that Behçet was the first modern author to group the various ophthalmic, dermatological, and orogenital lesions together as a syndrome.

However, during the annual meeting of the Medical Society of Athens on 15 November 1930, Benediktos Adamantiades
(1875-1962), ${ }^{4-6}$ Greek ophthalmologist from Prussa, Asia minor (nowadays Bursa, Turkey), presented a lecture entitled "A case of relapsing iritis with hypopyon", describing a 20 year old male patient with the three cardinal signs of the disease. The disease had begun at the age of 18 with oedema and ulcerations at the left leg diagnosed as thrombophlebitis. During the following two years (1928-30) the patient developed recurrent iritis with hypopyon in both eyes, which led to 
H EN A $\Theta H N A I \Sigma$

\section{IATPIKH ETAIPEIA}

ПРАКTIKA

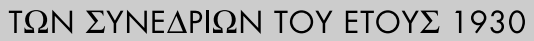

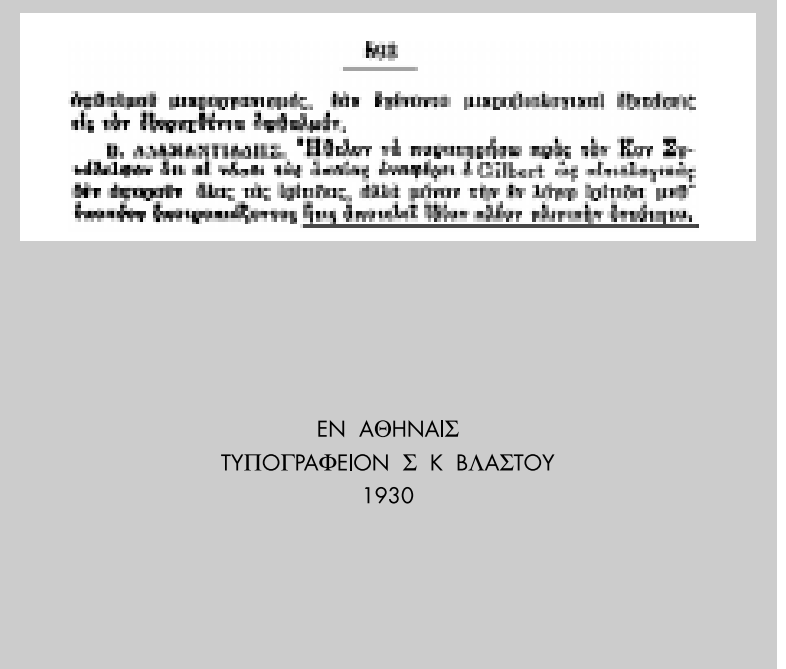

Figure 1 Original text of the response of $B$ Adamantiades to the comment of $V$ Vasilopoulos during the annual meeting of the Medical Society of Athens on 15 November 1930, proving his belief that his reported case constituted a new clinical entity.

blindness and atrophy of the optic nerve, scrotal ulcers healing with scars, oral aphthous ulcers, and a sterile arthritis of both knees. The last three signs were recurrent. Bacterial cultures of knee and anterior eye chamber punctures were sterile and the inoculation experiments in animals were negative, while staphylococci had grown in cultures from scrotal ulcers and a tonsilar abscess.

In the same year the lecture was published in the Proceedings of the Medical Society of Athens ${ }^{7}$ and in the following year in the French journal Annales d'Oculistique. ${ }^{8}$ Adamantiades connected the genital ulcers, the arthritis, and the ocular disease as signs of a single disease. He referred to publications by Reis (1906) and Gilbert (1920), who described similar cases, and backed the hypothesis of a bacterial, focal illness induced by staphylococci, which had been initiated by Gilbert (1925). ${ }^{9}$ He also responded to the comment of the physician $\mathrm{V}$ Vasilopoulos that the case can be classified as the already described, so-called "metastatic ophthalmias", which indicate a generalised infection, stating "I would like to comment to my colleague that the disease which reports Gilbert as aetiological (notice: induced by staphylococci) does not correlate with all types of iritis, but to this iritis with recurrent hypopyon, which now constitutes itself a clinical entity" (fig 1).

In 1946 Adamantiades reported on two further patients and defined thrombophlebitis as the fourth cardinal sign of the disease ${ }^{10}$ Later, he presented the first classification of the disease by describing the ocular, mucocutaneous, and systemic forms in a review. ${ }^{11}$ He pointed out that the disease can occur for years as a monosymptomatic or oligosymptomatic disorder and that eye involvement and severe prognosis are more common in men than in women. In this work he also proposed the first diagnostic criteria.

The term "Adamantiades-Behçet's disease" honours both men who first described the several manifestations which constitute an autonomous disease and is, therefore, proposed for naming this disorder.

\section{Authors' affiliations}

C C Zouboulis, Department of Dermatology, University Medical Centre Benjamin Franklin, The Free University of Berlin, Berlin, Germany

P Kaklamanis, Medical Centre, Athens, Greece

Correspondence to: Professor C C Zouboulis, Department of Dermatology, University Medical Centre Benjamin Franklin, The Free University of Berlin, Fabeckstrasse 60-62, 14195 Berlin, Germany; zouboulis@medizin.fu-berlin.de

Accepted 8 October 2002

\section{REFERENCES}

1 Leiba M, Sidy Y, Gur H, Leiba A, Ehrenfeld M. Behçet's disease and thrombophilia. Ann Rheum Dis 2001;60:1081-5.

2 Ehrlich GE. Behçet's disease and thrombophilia. Ann Rheum Dis 2002;61:381.

3 Leiba M, Sidy Y, Gur H, Leiba A, Ehrenfeld M. Authors' reply. Ann Rheum Dis 2002;61:381.

4 Fronimopoulos J, Lambrou N, Laskaratos J, Tourmousis A. Der Augenarzł B. Adamandiadis und die Geschichte des "Adamandiadis-Behçet-Syndroms". Klin Monatbl Augenheilkd "Adamaindiad:651-5.

5 Dimakakos PB, Tsiligiris B, Kotsis T. The physician B. Adamantiades and his contribution to the disease Adamantiades-Behçet. Int Angiol 1999; 18:176-81.

6 Zouboulis ChC. Benediktos Adamantiades and his forgotten contributions to medicine. Eur J Dermatol 2002;12:471-4.

7 Adamantiades B. A case of relapsing iritis with hypopyon (in Greek) Archia latrikis Etairias (Proceedings of the Medical Society of Athens) 1930:586-93.

8 Adamantiades B. Sur un cas d'iritis à hypopion récidivant. Ann Ocul (Paris) 1931;168:271-8.

9 Zouboulis ChC, Keitel W. A historical review of early descriptions of Adamantiades-Behçet's disease. J Invest Dermatol 2002;1 19:201-5. 10 Adamantiades B. La thrombophlébite comme quatrième symptome de I'iritis récidivante à hypopyon. Ann Ocul (Paris) 1946;179:143-8.

11 Adamantiadis $\mathbf{B}$. Le symptome complexe de l'uvéite récidivante à hypopyon. Ann Ocul (Paris) 1953;186:846-56. 


\title{
Polymicrobial septic arthritis in a patient with Wilson's disease
}

\author{
A M Oliver, J W Baddley, S L Bridges Jr
}

Ann Rheum Dis 2003;62:693-694

S eptic arthritis should be excluded in patients with new onset inflammatory polyarthritis and a history of organ transplant on immunosuppressive drugs or diabetes. Unusual organisms or polymicrobial joint infection may be present, even in the absence of bacteraemia or abnormal radiographs, and a history of prior infections may provide valuable clues.

\section{CASE REPORT}

A 35 year old white man was seen for pain and swelling in both wrists and the right knee for about three weeks. He was diagnosed with Wilson's disease at age 23 and underwent orthotopic liver transplant for cirrhosis one year later. Past history included personality disorder, choreiform movements, hypertension, diabetes mellitus, and renal insufficiency (serum creatinine $220-330 \mu \mathrm{mol} / \mathrm{l}$ ). There were no symptoms of carpal tunnel syndrome. The drugs he was taking were prednisone $10 \mathrm{mg} /$ day, mycophenolate mofetil $1000 \mathrm{mg}$ twice daily, atenolol, and insulin. He had taken cyclosporin until six months previously, but it was discontinued because of worsening renal insufficiency. He had an intrahepatic abscess due to Enterococcus faecalis six months previously, which was treated with drainage and several weeks of intravenous ampicillin and gentamicin through a Hickman catheter in the left subclavian vein. The catheter was removed about two months before the initial clinic visit; the tip was not sent for culture.

On examination, there was proliferative synovitis in both wrists without limitation of range of motion. There was a large effusion and limited flexion of the right knee. Radiographs of the hands, wrists, knees, and shoulders were unremarkable; no chondrocalcinosis was noted. Seventy five millilitres of serosanguinous fluid were aspirated from the right knee (white blood cell count $9.75 \times 10^{9} /$; red blood cell count $\left.8.5 \times 10^{9} / 1\right)$. No crystals were observed and the Gram stain was negative. Synovial fluid culture grew Enterococcus faecalis, Enterobacter sakazakii, and Candida albicans. Arthrocentesis of the left wrist yielded no fluid. Blood cultures were negative.

Abdominal magnetic resonance imaging (MRI) disclosed no hepatic abscess. Left wrist MRI showed proliferative synovitis but no abscess. Because of renal insufficiency, negative blood cultures, and absence of abscesses, he was treated with intravenous ampicillin and fluconazole rather than amphotericin. After one week in hospital, all three joints improved dramatically, and the arthritis completely in another week. He was given a six week course of oral ciprofloxacin and fluconazole after discharge. One month after completing a course of antibiotics, he presented with recurrent pain and swelling in both wrists and the right knee. Synovial fluid from the right knee again grew Candida albicans; fluconazole was reinstituted. His joint symptoms resolved completely and have not recurred during suppressive treatment, which he has taken for about 12 months.

\section{DISCUSSION}

Given this patient's history of diabetes, prior hepatic abscess, and Hickman catheter, and immunosuppressive drugs (mycophenolate and corticosteroids), septic arthritis was a strong possibility. Candidal arthritis is rare in immunocompetent subjects, but occurs in intravenous drug users and immunocompromised subjects. In this patient, transient candidaemia, possibly from a contaminated Hickman catheter, might have led to septic arthritis. Candidal arthritis most commonly affects the knee or hip, followed by the shoulder and ankle, ${ }^{1}$ and axial joints may be affected in intravenous drug users. Blood cultures are usually negative. In addition to adequate drainage of the joint, amphotericin B and oral or intravenous fluconazole have been used successfully for the treatment of Candida arthritis. ${ }^{2}$ Because of the patient's renal insufficiency and lack of systemic illness, fluconazole was given for a prolonged course. Typically, in the patient with normal renal function, 2-3 weeks of amphotericin B followed by prolonged treatment (6-12 months) with fluconazole is required for successful treatment. ${ }^{23}$

Enterococcus faecalis, previously isolated from a hepatic abscess, might have seeded the joints through haematogenous spread. Enterobacter sakazakii (formerly called yellowpigmented $E$ cloacae) is an opportunistic Gram negative bacillus. Enterobacter strains rarely cause primary human disease, but frequently colonise patients in hospital, and can cause wound, respiratory, and urinary tract infections. ${ }^{4}$ Enterobacter sakazakii meningitis or sepsis has been reported in neonates fed contaminated powdered milk. Only four cases of infection have been reported in adults, ${ }^{5}$ including two bronchopneumonia (both coinfected with Staphylococcus aureus), and one patient each with biliary sepsis and sepsis with acute respiratory distress syndrome. The role of Enterobacter sakazakii in this patient is difficult to ascertain; it may represent a nonpathogenic coinfection.

Wilson's disease (hepatolenticular degeneration) is a rare autosomal recessive condition caused by mutations in the ATP7B gene, which encodes a copper transporting $\mathrm{P}$ type ATPase expressed primarily in the liver and kidney. ${ }^{6}$ As liver function declines, excess copper accumulates in the brain, cornea, and kidney. Arthropathies associated with Wilson's disease are fairly common ${ }^{7-9}$ and usually affect large joints, but a distribution similar to rheumatoid arthritis has been reported. Radiographic changes include chondrocalcinosis and premature osteoarthritic changes such as osteophytes, subchondral cysts, and cartilage loss. ${ }^{10}$ The joint disease is thought to be in part due to aberrant copper deposition in the cartilage. ${ }^{9}$ Liver transplant generally ameliorates neurological and psychiatric manifestations, ${ }^{6}$ but it is unclear whether it helps arthropathy.

In summary, this case highlights the differential diagnosis of new onset arthritis in diabetic transplant patients taking immunosuppressive drugs. Arthritic problems of patients with Wilson's disease are discussed. Successful suppressive treatment of Candida arthritis with fluconazole was accomplished in this patient.

\section{ACKNOWLEDGEMENT}

The authors thank Dr Gene Ball for critical review of the manuscript.

\section{Authors' affiliations}

A M Oliver, J W Baddley, S L Bridges Jr, University of Alabama at Birmingham, Alabama, USA 
Correspondence to: Dr S L Bridges Jr, Division of Clinical Immunology and Rheumatology, 415 Lyons-Harrison Research Building, University of Alabama at Birmingham, Birmingham, AL 35294-0007, USA;

lbridges@uab.edu

Accepted 13 November 2002

\section{REFERENCES}

1 Cuende E, Barbadillo C, Mazzucchelli R, Isasi C, Trujillo A, Andreu JL. Candida arthritis in adult patients who are not intravenous drug addicts: report of three cases and review of the literature. Semin Arthritis Rheum 1993;22:224-41.

2 Rex JH, Walsh TJ, Sobel JD, Filler SG, Pappas PG, Dismukes WE, et al. Practice guidelines for the treatment of candidiasis. Infectious Diseases Society of America. Clin Infect Dis 2000;30:662-78.

3 Perez-Gomez A, Prieto A, Torresano M, Diez E, Mulero J, Labiano I, et al. Role of the new azoles in the treatment of fungal osteoarticular infections. Semin Arthritis Rheum 1998;27:226-44.
4 Eisenstein BI, Zaleznik DF. Enterobacteriaceae. In: Mandell GL, et al, eds. Principles and practice of infectious diseases. Edinburgh: Churchill Livingstone, 2000

5 Lai KK. Enterobacter sakazakii infections among neonates, infants, children, and adults. Case reports and a review of the literature. Medicine (Baltimore) 2001;80:113-22.

6 Gahl W. Wilson disease. In: Goldman L, Bennett JC, eds. Cecil textbook of medicine. Philadelphia: Saunders, 2002.

7 Kaklamanis $\mathbf{P}$, Spengos M. Osteoarticular changes and synovial biopsy findings in Wilson's disease. Ann Rheum Dis 1973;32:422-7.

8 Golding DN, Walshe JM. Arthropathy of Wilson's disease. Study of clinical and radiological features in 32 patients. Ann Rheum Dis 1977;36:99-111

9 Menerey KA, Eider W, Brewer GJ, Braunstein EM, Schumacher HR, Fox $\mathrm{IH}$. The arthropathy of Wilson's disease: clinical and pathologic features. I Rheumatol 1988:15:331-7.

10 Balint G, Szebenyi B. Hereditary disorders mimicking and/or causing premature osteoarthritis. Baillieres Best Pract Res Clin Rheumatol 2000; 14:219-50.

\section{Reduction in plasma homocysteine level in patients with rheumatoid arthritis given pulsed glucocorticoid treatment}

\section{P E Lazzerini, P L Capecchi, S Bisogno, M Galeazzi, R Marcolongo, F Laghi Pasini}

$\mathrm{H}$ igh levels of homocysteine are commonly found in patients with rheumatoid arthritis (RA), thus accounting, at least in part, for the high rate of mortality for cardiovascular events in these subjects. ${ }^{1-5}$ The mechanisms responsible for hyperhomocysteinaemia in RA are not clear. However, drugs such as methotrexate and sulfasalazine affect homocysteine metabolism, interfering with vitamin metabolism and absorption. ${ }^{135}$ Furthermore, an increased use or accelerated catabolism of vitamin B6 has been shown in chronic inflammatory diseases, particularly RA. ${ }^{26-8}$

Recently, it has been shown that rats treated with cortisol have plasma homocysteine levels lower than controls. ${ }^{9}$ Glucocorticoids increase the activity of betaine-homocysteine methyltransferase, which transforms homocysteine in methionine with consumption of betaine as methyl donor coenzyme. ${ }^{10}$ Moreover, steroids may produce genomic inhibition of several cytokines, leading to an increased availability of vitamin B6.

The effect of glucocorticoids on homocysteine plasma level was evaluated by high performance liquid chromatography (HPLC) in nine patients with active RA (eight women, one man; mean (SD) age 53.4 (16) years) with a mean (SD) duration of disease of 10.6 (8) years, in an open, uncontrolled pilot study. Serum folate (by radioimmunoassay (RIA)), vitamin B12 (RIA), vitamin B6 (HPLC), betaine (HPLC), creatinine (Syncron Chemical System LX 20, Bechman), and C reactive

Table 1 Changes in serum levels of the variables under study. Values are expressed as mean (SD)

\begin{tabular}{|c|c|c|c|c|}
\hline & Baseline & 2 Weeks & 3 Months & 6 Months \\
\hline $\begin{array}{l}\text { Homocyste } \\
\mu \mathrm{mol} / \mathrm{l} \\
\Delta \%\end{array}$ & $\begin{array}{c}\text { prmal range < } \\
13.1(3.5)\end{array}$ & $\begin{array}{l}11.0(3.6)^{* * *} \\
-16.9\end{array}$ & $\begin{array}{l}10.6(2.7)^{* * *} \\
-18.3\end{array}$ & $\begin{array}{l}9.6(2.7)^{* * *} \\
-26.0\end{array}$ \\
\hline $\begin{array}{c}\text { Creatinine } \\
\mu \mathrm{mol} / \mathrm{l} \\
\Delta \%\end{array}$ & $\begin{array}{l}\text { al range } 50-1 \\
58(18)\end{array}$ & $\begin{array}{l}64(9) \\
+8.6\end{array}$ & $\begin{array}{l}65(18) \\
+9.1\end{array}$ & $\begin{array}{l}65(18) \\
+8.9\end{array}$ \\
\hline $\begin{array}{l}\text { Folate (nor } \\
\mathrm{ng} / \mathrm{ml} \\
\Delta \%\end{array}$ & $\begin{array}{c}\text { nge } 3-17 \mathrm{ng} / \\
6.3(3.3)\end{array}$ & $\begin{array}{l}6.7(5.0) \\
+6.0\end{array}$ & $\begin{array}{l}6.8(3.0) \\
+6.4\end{array}$ & $\begin{array}{l}6.7(2.0) \\
+5.8\end{array}$ \\
\hline $\begin{array}{c}\mathrm{B} 12 \text { (norm } \\
\mathrm{pg} / \mathrm{ml} \\
\Delta \%\end{array}$ & $\begin{array}{r}\text { e 200-950 p } \\
498.4(155\end{array}$ & $\begin{array}{l}478.2(142) \\
-3.7\end{array}$ & $\begin{array}{l}484.5(231) \\
-3.1\end{array}$ & $\begin{array}{l}498.9(218) \\
+1.2\end{array}$ \\
\hline $\begin{array}{c}\text { B6 lnorma } \\
\mathrm{ng} / \mathrm{ml} \\
\Delta \%\end{array}$ & $\begin{array}{l}4.3-17.9 \mathrm{ng} \\
5.7(2.8)\end{array}$ & $\begin{array}{l}6.2(3.6) \\
+8.4\end{array}$ & $\begin{array}{l}5.7(2.4) \\
+0.3\end{array}$ & $\begin{array}{l}5.7(2.5) \\
-0.1\end{array}$ \\
\hline $\begin{array}{c}\text { Betaine (no } \\
\mu \mathrm{mol} / \mathrm{l} \\
\Delta \%\end{array}$ & $\begin{array}{c}\text { ange } 20-144 \\
49.7(21)\end{array}$ & $\begin{array}{l}42.7(24) \\
-11.5\end{array}$ & $\begin{array}{l}38.1(20)^{*} \\
-19.1\end{array}$ & $\begin{array}{l}35.0(18)^{* *} \\
-25.3\end{array}$ \\
\hline $\begin{array}{l}\text { CRP /normc } \\
\mathrm{mg} / \mathrm{l} \\
\Delta \%\end{array}$ & $\begin{array}{r}e<5 \mathrm{mg} / 1) \\
35.7(15)\end{array}$ & $\begin{array}{l}20.9(13)^{*} \\
-42.3\end{array}$ & $\begin{array}{l}23.9(10) \\
-29.2\end{array}$ & $\begin{array}{l}24.2(11) \\
-30.3\end{array}$ \\
\hline
\end{tabular}


protein (CRP) (Syncron Chemical System LX 20, Bechman) were also evaluated. Current treatment included methotrexate $(\mathrm{n}=7$, mean dose $10.7 \mathrm{mg}$ weekly), corticosteroids $(\mathrm{n}=6$, mean dose $7.7 \mathrm{mg}$ daily), and sulfasalazine $(\mathrm{n}=1$, mean dose 1500 mg daily). All patients had normal renal function and vitamin plasma levels, and they were not affected with any concomitant infections or neoplasms or cardiovascular diseases.

After obtaining informed consent, all subjects underwent treatment with three $1 \mathrm{~g}$ methylprednisolone intravenous administrations every other day. During the observation period patients with RA continued receiving their usual treatment. Patients, including those treated with methotrexate, did not receive vitamin supplementation or continuous nonsteroidal anti-inflammatory drug (NSAID) treatment. Measurements were performed on fresh blood samples before the first drug infusion, and two weeks, three months, and six months after the onset of the treatment.

Patients with RA given steroid pulse therapy showed an early and progressive reduction in homocysteine plasma level. A similar decrease was also seen in the betaine plasma level In contrast, CRP, after an initial reduction, showed a longlasting steady state period. No significant changes in creatinine and vitamin status were seen (table 1). A significant correlation was found between the mean values of homocysteine and betaine (fig 1). Interestingly, homocysteine plasma levels in the three patients not resuming oral steroids after the glucocorticoid intravenous bolus, tended to return to baseline $(-17 \%,-12.5 \%,-11.3 \%$, after two weeks, three months, and six months, respectively), whereas in the six patients continuing to receive steroids orally, homocysteine plasma levels decreased further $(-16.3 \%,-21.4 \%,-36.2 \%$, respectively).

Our results show that glucocorticoid pulse therapy is associated with a rapid and longlasting decrease in the homo-

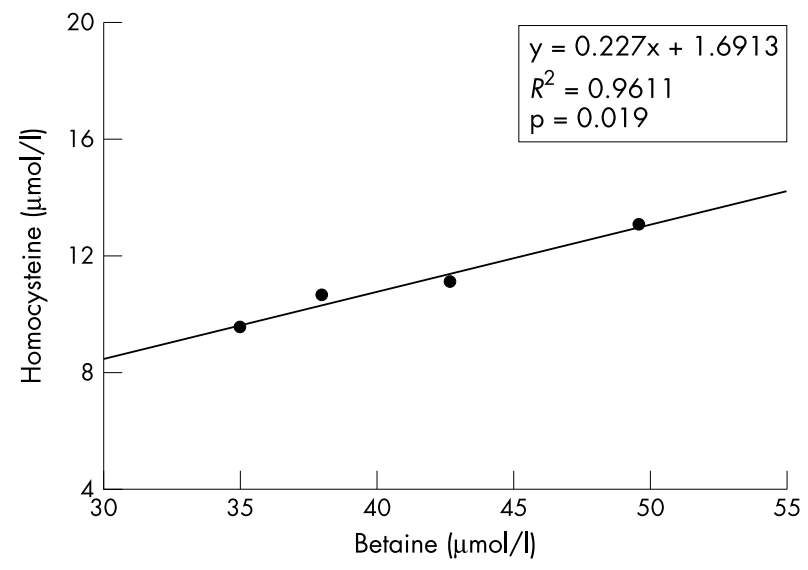

Figure 1 Correlation between the mean values of homocysteine and betaine in plasma. Statistical analysis by the Spearman's correlation coefficient. cysteine plasma level in patients with active RA with a possible impact on cardiovascular risk. Indeed, continuing oral treatment with low dose glucocorticoids seems to stabilise the effects on homocysteine metabolism of a single cycle of high dose administration of steroids, which in turn would "switch on" the metabolic cascade of homocysteine.

Although our data seem to suggest a role for the betaine-homocysteine methyltransferase pathway, the observation that CRP tended to decrease as a possible expression of the reduced activity of the disease, does not allow us to rule out the possibility that lower levels of inflammation related humoral factors may contribute to the observed reduction in homocysteine.

The major limitations of our study is that it was open and uncontrolled, and with a small number of patients. A larger study, also including a control group of patients with RA, is now in progress.

\section{Authors' affiliations}

P E Lazzerini, P L Capecchi, F Laghi Pasini, Clinical Immunology Unit, Department of Clinical Medicine and Immunological Sciences, University of Siena, Policlinico "Le Scotte", 53100, Siena, Italy

S Bisogno, M Galeazzi, R Marcolongo, Institute of Rheumatology,

Department of Clinical Medicine and Immunological Sciences, Policlinico

"Le Scotte", 53100, Siena, Italy

Correspondence to: Professor F Laghi Pasini; laghi@unisi.it

Accepted 30 December 2002

\section{REFERENCES}

1 Krogh Jensen $M$, Ekelund S, Svendsen L. Folate and homocysteine status and haemolysis in patients treated with sulphasalazine for arthritis. Scand J Clin Lab Invest 1996:56:421-9.

2 Roubenoff R, Dellaripa P, Nadeau MR, Abad IW, Muldoon BA, Selhub $\mathrm{J}$, et al. Abnormal homocysteine metabolism in rheumatoid arthritis. Arthritis Rheum 1997;40:718-22.

3 Haagsma CJ, Blom HJ, van Riel PL, van't Hof MA, Giesendorf BA, van Oppenraaij-Emmerzaal D, et al. Influence of sulphasalazine, methotrexate, and the combination of both on plasma homocysteine concentrations in patients with rheumatoid arthritis. Ann Rheum Dis 1999;58:79-84

4 Landewe RB, van den Borne BE, Beedveld FC, Dijkmans BA. Methotrexate effects in patients with rheumatoid arthritis with cardiovascular comorbidity. Lancet 2000;355:1616-17.

5 Erb N, Kitas GD. Homocysteine modulation as a reason for continuous folic acid supplementation in methotrexate-treated rheumatoid arthritis patients. Rheumatology (Oxford) 2001;40:715-16.

6 Roubenoff R, Roubenoff RA, Selhub J, Nadeau MR, Cannon JG, Freeman LM, et al. Abnormal vitamin B6 status in rheumatoid cachexia: association with spontaneous tumor necrosis factor alpha production and markers of inflammation. Arthritis Rheum 1995;38:105-9.

7 Rall LC, Meydani SN. Vitamin B6 and immune competence. Nutr Rev 1993;51:217-25

8 McCarty MF. Increased homocyst(e)ine associated with smoking, chronic inflammation, and aging may reflect acute-phase induction of pyridoxal phosphatase activity. Med Hypoth 2000;55:289-93

$9 \operatorname{Kim~MH}$, Kim E, Passen EL, Meyer J, Kang SS. Cortisol and estradiol: nongenetic factors for hyperhomocyst(e)inemia. Metabolism 1997;46:247-9.

10 Mudd SH, Levy HL, Skovby F. Disorders of transulfuration. In: Scriver CR, Baudet AL, Sly WS, et al, eds. The metabolic and molecular bases of inherited disease. New York: McGraw-Hill, 1995:1279-327. 